\title{
Oceanographic habitats of two sympatric North Pacific albatrosses during the breeding season
}

\author{
K. David Hyrenbach ${ }^{1, *}$, Patricia Fernández ${ }^{2}$, David J. Anderson ${ }^{2}$ \\ ${ }^{1}$ Scripps Institution of Oceanography, University of California San Diego, 9500 Gilman Drive, La Jolla, \\ California 92093-0208, USA \\ ${ }^{2}$ Department of Biology, Wake Forest University, Winston-Salem, North Carolina 27109-7325, USA
}

\begin{abstract}
We characterized the movements and oceanographic habitats of black-footed (Phoebastria nigripes) and Laysan ( $P$. immutabilis) albatrosses during the brooding and the rearing periods of the breeding cycle. Analyses of satellite telemetry data in conjunction with remotely sensed sea surface temperature and chlorophyll concentrations revealed substantial differences in habitat use between these 2 sympatrically breeding species. During the brooding period, black-footed albatross restricted their foraging to tropical waters $\left(>20^{\circ} \mathrm{C}\right)$, while Laysan albatross ventured into the colder waters of the Transition Domain $\left(15\right.$ to $\left.12^{\circ} \mathrm{C}\right)$ and the Subarctic Frontal Zone $\left(12\right.$ to $\left.10^{\circ} \mathrm{C}\right)$. This pelagic segregation became more apparent with the expansion of the foraging ranges later in the breeding season. During the chick-rearing period, black-footed albatross commuted to the California Current $\left(15\right.$ to $\left.12^{\circ} \mathrm{C}\right)$ and Laysan albatross foraged in subarctic $\left(<12^{\circ} \mathrm{C}\right)$ and Transition Domain $\left(15\right.$ to $\left.12^{\circ} \mathrm{C}\right)$ waters. The foraging behavior of albatrosses was scale-dependent. Over macro-mega scales of (1000 to $3000 \mathrm{~km}$ ) albatross dispersion was influenced by large-scale ocean productivity patterns and water mass distributions. Over smaller coarse-meso scales of (10 to $100 \mathrm{~km}$ ) albatrosses focused their foraging activities along oceanic habitats characterized by elevated ocean productivity and prey aggregation. The foraging birds traveled more slowly in the vicinity of highly productive continental shelves (central California to Washington State, Aleutian Islands), and hydrographic fronts (Transition Domain, North Pacific Transition Zone Chlorophyll Front). Conversely, the satellite tracked albatrosses commuted rapidly over tropical and subtropical waters between these foraging areas and the breeding colony. These results highlight the significance of macro-mega scale of (1000 to $3000 \mathrm{~km}$ ) water mass distributions and coarse-meso scale (10 to $100 \mathrm{~km}$ ) hydrographic features to far-ranging marine predators, and underscore the need to understand how physical-biological processes sustain predictable regions of elevated ocean productivity and prey aggregation in marine systems.
\end{abstract}

KEY WORDS: Area restricted searching $\cdot$ Frontal systems $\cdot$ Habitat use $\cdot$ Kernel analysis $\cdot$ Phoebastria immutabilis $\cdot$ Phoebastria nigripes $\cdot$ Satellite telemetry $\cdot$ Spatial segregation

\section{INTRODUCTION}

Marine productivity is not distributed uniformly across ocean basins. Instead, chlorophyll concentration, zooplankton biomass, nekton abundance, and seabird numbers are influenced by macro-mega scale

${ }^{*}$ Present address: Duke University Marine Laboratory, 135 Duke Marine Lab Road, Beaufort, North Carolina 28516, USA. E-mail: khyrenba@duke.edu
(1000 to $3000 \mathrm{~km}$ ) current systems and oceanographic domains, and by coarse-meso scale (10 to $100 \mathrm{~km})$ processes that promote water-column mixing and convergence (Aron 1962, Haury et al. 1978, Hunt \& Schneider 1987, Longhurst 1998). Because pelagic systems are heterogeneous in space and time, it has generally been assumed that oceanic seabirds use prey patches that are scarce and unpredictable (Lack 1968, Jouventin \& Weimerskirch 1990, Weimerskirch et al. 1994b). Low prey availability and large distances be- 
tween food patches have been invoked to explain the vast foraging ranges and the morphological (e.g. low wing loading, high wing aspect ratios), physiological (e.g. energy storage as stomach oil, low metabolic rates), and behavioral (e.g. dynamic soaring, alternation of long and short foraging trips) characteristics that allow breeding seabirds to provision concentrated energy to the nest (Warham et al. 1976, Warham 1977 , Pennycuick 1987, Jouventin \& Weimerskirch 1990, Weimerskirch et al. 1994a, 2000, Nicholls et al. 1997). Albatrosses are a prime example of marine birds suited for a pelagic existence (Warham 1990).

Broadscale (100 to $1000 \mathrm{~km}$ ) vessel-based surveys have revealed that albatrosses inhabit ocean regions within specific ranges of temperature and salinity termed water masses, and often aggregate at hydrographic and bathymetric gradients such as frontal systems, and continental shelves and slopes (Stahl et al. 1985, Wahl et al. 1989, Veit \& Hunt 1992). These observations, however, have been constrained by the tendency of albatrosses to follow survey vessels, and by the inability of observers to determine the origin, gender, and reproductive status of birds sighted at sea (Prince et al. 1999, Hyrenbach 2001).

In recent years, technological developments have advanced our understanding of the foraging ecology and the habitats of pelagic seabirds. In particular, the advent of satellite telemetry in the early 1990s facilitated the study of the movements and the foraging ranges of individually known birds. Pioneering research in the Southern Ocean revealed that wandering albatross Diomedea exulans routinely traveled $O(1000$ $\mathrm{km}$ ) between successive provisioning visits to their chicks, and repeatedly commuted to specific oceanic sectors (Jouventin \& Weimerskirch 1990). Subsequent telemetry studies have documented gender-based differences in albatross reproductive strategies (e.g. resource allocation to chicks) and dispersion (e.g. foraging range and trip duration), as well as distinct species-specific habitat use patterns (Prince et al. 1992, 1999, Veit \& Prince 1997, Weimerskirch et al. 1997, Waugh et al. 1999, Fernández et al. 2001). Moreover, satellite telemetry studies have highlighted the significance of specific oceanic habitats such as frontal areas (Rodhouse et al. 1996, Prince et al. 1999), continental shelves (Anderson et al. 1998, Gremillet et al. 2000, Fernández et al. 2001), and shallow banks (Cherel \& Weimerskirch 1995, Weimerskirch et al. 1997) as foraging grounds for breeding albatrosses.

This research focused on the 2 most numerous North Pacific albatross species: the black-footed (Phoebastria nigripes) and the Laysan ( $P$. immutabilis) albatrosses. These species breed sympatrically on islands along the Hawaiian Chain and have broad distributions spanning tropical, subtropical, and subarctic latitudes $\left(15^{\circ}\right.$ to $53^{\circ} \mathrm{N}$ for the black-footed albatross and $8^{\circ}$ to $59^{\circ} \mathrm{N}$ for the Laysan albatross), and from the west coast of North America $\left(120^{\circ} \mathrm{W}\right)$ to Japan $\left(140^{\circ} \mathrm{E}\right)$ (Shuntov 1974, Whittow 1993a, b).

Black-footed and Laysan albatrosses inhabit a vast and heterogeneous environment. Over macro-mega scales (1000 to $3000 \mathrm{~km}$ ) phytoplankton, zooplankton, and nekton standing stocks increase across the North Pacific from subtropical regions to subarctic waters, indicating strong latitudinal gradients in ocean productivity (Aron 1962, Vinogradov et al. 1997, Longhurst 1998). Superimposed on this latitudinal ecotone, another productivity gradient extends from the center of the Subtropical Gyre (approximately $30^{\circ} \mathrm{N}$ ) toward the highly productive waters along the periphery of the North Pacific (Barber \& Smith 1981, Vinogradov 1981, Longhurst 1998). Over smaller coarse-meso scales (10 to $100 \mathrm{~km}$ ), a variety of physical and biological processes influence localized production and prey dispersion across the North Pacific. Bathymetric features (e.g. shelf breaks, seamounts) and water mass boundaries (e.g. eddies, fronts) enhance water-column mixing, stimulate localized production, and aggregate planktonic prey at secondary convergence zones (Wolanski \& Hamner 1988, Franks 1992, Larson et al. 1994, Springer et al. 1996, Polovina et al. 2001).

The objective of this research was to determine how oceanographic variability influences the dispersion and the foraging behavior of 2 sympatrically breeding farranging seabirds. More specifically, this study contrasts the habitats used by black-footed and Laysan albatrosses during the brooding and the chick-rearing periods of the breeding season. These analyses address the significance of large-scale $O(1000 \mathrm{~km})$ water mass distributions and small-scale (10 to $100 \mathrm{~km})$ areas of high productivity and prey aggregation. The 3 basic questions underlying this research are: (1) whether North Pacific albatrosses forage in predictable oceanic habitats characterized by specific water depth, ocean temperature, and chlorophyll concentrations; (2) do foraging albatrosses segregate at sea by gender and by species; and (3) does habitat use change during the breeding season. This study complements a previous description of North Pacific albatross foraging destinations by Fernández et al. (2001).

\section{MATERIALS AND METHODS}

Study site. We studied the movements, foraging destinations, and oceanic habitats of 2 subtropical Hawaiian albatross species nesting at Tern Island $\left(23.878^{\circ} \mathrm{N}\right.$, $\left.166.288^{\circ} \mathrm{W}\right)$, French Frigate Shoals, Hawaii during the 1998 breeding season (January to July). Tern Island lies in the middle of the North Pacific Subtropical Gyre: 
$3200 \mathrm{~km}$ from the Aleutian Chain (AC), $4500 \mathrm{~km}$ from California (CA), and $4300 \mathrm{~km}$ from the Kamchatka Peninsula (KP) (Fig. 1). Breeding black-footed albatross arrive at the colony in mid-October, copulate, depart to sea in a pre-breeding exodus, and then return to lay 1 egg by early November. Chicks hatch between the middle of January and the first week in February, and fledge by the end of June (Whittow 1993a). The Laysan albatross reproductive cycle is offset by $2 \mathrm{wk}$. Breeding birds arrive at the colony at the beginning of November and lay 1 egg by late November - early December. Chicks hatch between the last week of January and the middle of February, and fledge by mid-July (Whittow 1993b).

We divided the breeding season into 3 periods defined by the reproductive schedule of each individual bird: (1) brooding (0 to $18 \mathrm{~d}$ after hatching); (2) chickrearing (19 to $140 \mathrm{~d}$ post-hatching); and (iii) postbreeding (after chicks fledge, $>140 \mathrm{~d}$ post-hatching) (Rice \& Kenyon 1962, Whittow 1993a,b). We classified foraging trips on the basis of the date of departure from the colony and considered forays that started after the death of a chick as post-breeding trips.

Satellite telemetry. We have previously described the methods employed to select study animals, determine their gender, attach Platform Transmitter Termi-

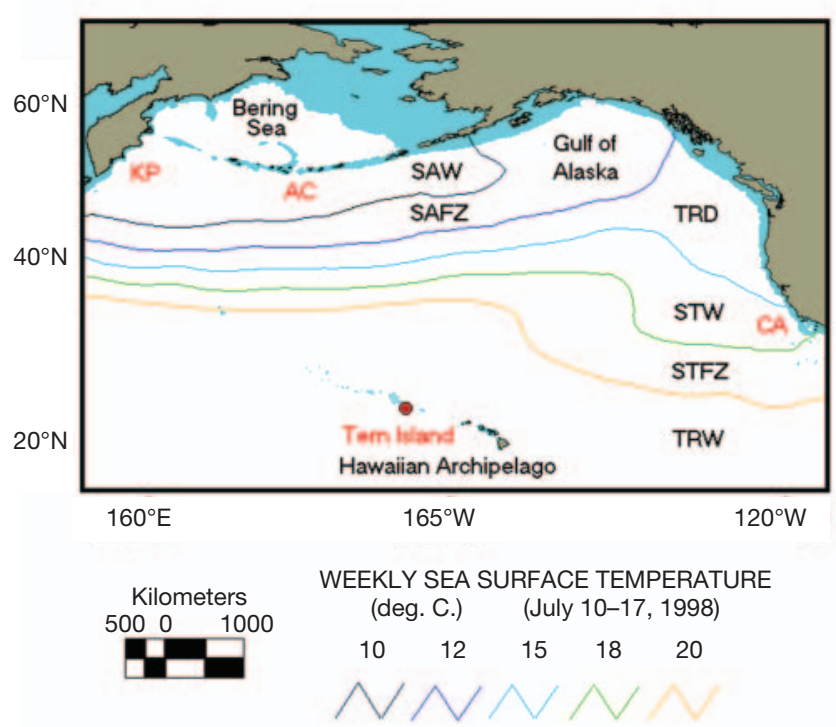

Fig. 1. The study area depicting the location of the albatross breeding colony at Tern Island $\left(23.878^{\circ} \mathrm{N}, 166.288^{\circ} \mathrm{W}\right)$ and the extent of distinct bathymetric domains and water masses. Continental shelves and slopes (seafloor depth $<3000 \mathrm{~m}$ ) are depicted by the blue shading. Water masses are defined on the basis of remotely sensed sea surface temperature isotherms during July 10 to 17, 1998. TRW: Tropical Water, STFZ: Subtropical Frontal Zone, STW: Subtropical Water, TRD: Transition Domain, SAFZ: Subarctic Frontal zone, SAW: Subarctic Water. AC: Aleutian Chain, CA: California, KP: Kamchatka Peninsula nals (PTTs), ground-truth PTT performance, assign deployment schedules, and use the Argos satellite system (Fernández et al. 2001). Briefly, PTT100 transmitters (Microwave Telemetry, Columbia, MD) used an 8:24 h on:off duty cycle, so transmitters operated $25 \%$ of the time they were deployed. However, black-out periods did not inhibit the analysis of albatross movements because over $93 \%(122 / 131)$ of the foraging trips we monitored exceeded $24 \mathrm{~h}$ in duration. We discarded the least accurate data supplied by Argos (Class B locations), as in our previous paper (Fernández et al. 2001). The remaining 3506 locations (85.6\% of the total) were accurate to within $10 \mathrm{~km}$. There were no gender-based or species-specific differences in the quality of the telemetry locations obtained during this study ( $G$-test, $G=3.759$, df $=12,0.99<\mathrm{p}<0.975$ ).

Analysis of albatross telemetry tracks. Satellite telemetry samples an animal's continuous movements at unevenly spaced intervals. The accurate depiction of the animal's trajectory can be enhanced by discarding unreasonable and uncertain telemetry locations. After excluding low quality (Class B) fixes, we calculated the movement rates between consecutive satellite locations using the great-circle formulation (Fitzpatrick \& Modlin 1986), and removed all fixes that required unrealistic flying speeds exceeding $80 \mathrm{~km} \mathrm{~h}^{-1}$ (Spear \& Ainley 1997). We also discarded tracks between locations that were separated by $<1$ or $>24 \mathrm{~h}$ because of the uncertainty associated with those tracks. For locations closely spaced in time $(<1 \mathrm{~h})$, the inherent errors in the Argos system constituted approximately 10 to $50 \%$ of the distance a bird could have traveled during that time. Moreover, it is highly unlikely that the tracked birds moved in a straight line between consecutive satellite fixes separated by long time intervals (>24 h).

Statistical analysis of telemetry data. Statistical analyses of telemetry data are often inhibited by the lack of sample independence, and by the inability to aggregate observations from individuals with different habitat use patterns and ranging behaviors (Aebischer et al. 1993). Moreover, telemetry locations collected sequentially from the same individuals may be serially correlated, and may thus not be treated as independent samples. In particular, successive telemetry locations for central place foragers are likely not independent because foraging trips begin and end at the breeding colony. Therefore, statistical analyses that include every telemetry location along a foraging trip may falsely reject the null hypothesis (Type I error) due to inflated sample sizes (i.e. pseudoreplication; Hurlbert 1984). We opted for a conservative approach and considered all telemetry locations gathered during a single foraging trip to be non-independent samples.

In fact, consecutive foraging trips by the same individual may not be truly independent either. Many 
petrels alternate long and short foraging trips that allocate resources alternatively to the adult and to the chick (Weimerskirch et al. 1994a). We showed earlier that the distances covered by individual brooding and rearing black-footed albatross during consecutive foraging trips were not correlated, suggesting that the birds were not alternating long and short forays or engaging in progressively longer trips. For Laysan albatrosses, on the other hand, the distances covered by individual birds during consecutive forays were positively correlated, suggesting that foraging trips lengthened as the brooding season progressed (Fernández et al. 2001). This lack of independence can be circumvented by analyzing only 1 foraging trip per individual (Gonzalez-Solis et al. 2000). Alternatively, all foraging trips taken by an individual can be combined and analyzed together. We resorted to the latter approach because we were interested in contrasting the behavior of individual birds during the brooding and rearing periods of the breeding cycle. Therefore, we calculated the median value of the metrics used to quantify albatross habitat use (sea surface temperature, chlorophyll concentration, seafloor depth) for every tracked bird during the brooding and rearing periods separately. This conservative approach reduced our sample size from 131 foraging trips to 29 individual birds (Table 1).

Telemetry studies have consistently revealed differences in the foraging behavior of individual birds from the same colonies (Prince et al. 1999, Gonzalez-Solis et al 2000, Fernández et al. 2001). Distinct individual

Table 1. Sample sizes used to characterize albatross foraging movements

\begin{tabular}{|c|c|c|c|c|c|c|}
\hline \multirow[t]{2}{*}{ Species } & \multirow[t]{2}{*}{ Gender } & \multirow{2}{*}{$\begin{array}{c}\text { Period } \\
\text { (chick age, } \\
\text { days) }\end{array}$} & \multicolumn{2}{|c|}{$\begin{array}{l}\text { Repeated measures } \\
\text { ANOVA }\end{array}$} & \multicolumn{2}{|c|}{$\begin{array}{l}\text { Generalized } \\
\text { linear models }\end{array}$} \\
\hline & & & $\begin{array}{c}\text { Number } \\
\text { of trips }\end{array}$ & $\begin{array}{l}\text { Number } \\
\text { of birds }\end{array}$ & $\begin{array}{c}\text { Number } \\
\text { of trips }\end{array}$ & $\begin{array}{l}\text { Number } \\
\text { of birds }\end{array}$ \\
\hline \multirow[t]{2}{*}{$\begin{array}{l}\text { Black-footed } \\
\text { albatross }\end{array}$} & Female & $\begin{array}{l}\text { Brooding } \\
(0-18)\end{array}$ & 22 & 5 & 24 & 6 \\
\hline & & $\begin{array}{l}\text { Rearing } \\
(19-140)\end{array}$ & 25 & 5 & 30 & 6 \\
\hline \multirow[t]{2}{*}{$\begin{array}{l}\text { Black-footed } \\
\text { albatross }\end{array}$} & Male & $\begin{array}{l}\text { Brooding } \\
(0-18)\end{array}$ & 1 & 1 & 16 & 6 \\
\hline & & $\begin{array}{l}\text { Rearing } \\
(19-140)\end{array}$ & 3 & 1 & 7 & 2 \\
\hline \multirow[t]{2}{*}{$\begin{array}{l}\text { Laysan } \\
\text { albatross }\end{array}$} & Female & $\begin{array}{l}\text { Brooding } \\
(0-18)\end{array}$ & 5 & 2 & 17 & 6 \\
\hline & & $\begin{array}{l}\text { Rearing } \\
(19-140)\end{array}$ & 8 & 2 & 10 & 3 \\
\hline \multirow[t]{2}{*}{$\begin{array}{l}\text { Laysan } \\
\text { albatross }\end{array}$} & Male & $\begin{array}{l}\text { Brooding } \\
(0-18)\end{array}$ & 10 & 4 & 15 & 6 \\
\hline & & $\begin{array}{l}\text { Rearing } \\
(19-140)\end{array}$ & 8 & 4 & 12 & 4 \\
\hline Total & & & 82 & 12 & 131 & 29 \\
\hline
\end{tabular}

habitat use patterns may be related to factors that are difficult to quantify during telemetry studies, such as differences in body condition (Weimerskirch et al. 1997, Weimerskirch \& Cherel 1998), and previous foraging experience. However, telemetry studies should account for behavioral disparities across individuals, because this variability could potentially obscure gender-based and species-specific differences in habitat selection and foraging behavior. We addressed disparate individual preferences by incorporating 'individual bird' effects as covariates (ANCOVA) and blocking factors (repeated measures ANOVA, generalized linear models) in our statistical analyses.

Defining pelagic habitats in the North Pacific Ocean. We characterized marine habitats in the North Pacific Ocean between January and July 1998 using 3 variables: sea surface temperature (SST), chlorophyll concentration ( $\mathrm{chl} a$ ), and seafloor depth. Although ocean temperature, chlorophyll concentration, and seafloor depth are correlated in the North Pacific (Vinogradov et al. 1997, Longhurst 1998), we considered these variables separately in our analyses.

We used filtered weekly averages of SST imagery from the Advanced Very High Resolution Radiometer (AVHRR) with a spatial resolution of $1^{\circ} \times 1^{\circ}$ latitude/longitude (Reynolds \& Smith 1994) compiled by the Pacific Marine Environmental Laboratory (www.ferret.noaa.gov/fbin/climate_server). Global comparisons have revealed that satellite-derived SST measurements are 0.3 to $0.4^{\circ} \mathrm{C}$ lower than vesselbased observations, with cross-correlations ranging between +0.3 and +0.7 (McClain et al. 1985). We considered 6 water masses defined on the basis of sea surface temperature: tropical waters $\left(>20^{\circ} \mathrm{C}\right)$, the Subtropical Frontal Zone $\left(20\right.$ to $\left.18^{\circ} \mathrm{C}\right)$, the Subtropical or Central Pacific Water Mass $\left(18\right.$ to $\left.15^{\circ} \mathrm{C}\right)$, the North Pacific Transition Domain $\left(15\right.$ to $\left.12^{\circ} \mathrm{C}\right)$, the Subarctic Frontal Zone (12 to $\left.10^{\circ} \mathrm{C}\right)$, and the Subarctic Domain $\left(<10^{\circ} \mathrm{C}\right)$ (Favorite et al. 1976, Lynn 1986, Roden 1991).

Chlorophyll concentrations were derived from sea-viewing wide field-ofview sensor (SeaWiFS) monthly composites with a spatial resolution of approximately $9 \mathrm{~km}$ (http://seawifs. gsfc.nasa.gov/SEAWIFS.html). SeaWiFS chlorophyll concentration estimates are within 30 to $50 \%$ of vessel-based observations (McClain et al. 1998), with the largest discrepancies in regions of high in situ chlorophyll concentrations between 1 and $10 \mathrm{mg} \mathrm{m}^{-3}$ (Kahru \& 
Mitchell 1999). We considered 4 productivity regimes based on remotely sensed chlorophyll standing stocks: oligotrophic (low productivity) waters with chlorophyll concentrations below $0.1 \mathrm{mg} \mathrm{m}^{-3}$; mesotrophic (intermediate productivity) waters ranging between 0.1 and $0.3 \mathrm{mg} \mathrm{m}{ }^{-3}$; eutrophic (high productivity) waters between 0.3 and $1 \mathrm{mg} \mathrm{m}^{-3}$; and enriched waters with chlorophyll concentrations above $1 \mathrm{mg} \mathrm{m}^{-3}$.

We obtained bathymetric data from the general bathymetric chart of the oceans (GEBCO) with a spatial resolution of approx. $100 \mathrm{~m}$ and no specified accuracy (www.ngdc.noaa.gov/mgg/gebco/gebco.html). We divided the North Pacific Ocean into 4 bathymetric domains: pelagic waters (deeper than $3000 \mathrm{~m}$ ); continental slopes (between 1000 and $3000 \mathrm{~m}$ ); continental shelves (between 200 and $1000 \mathrm{~m}$ ), and coastal waters (shallower than $200 \mathrm{~m}$ ). Previously, albatross telemetry studies have considered pelagic $(>3000 \mathrm{~m}$ ), shelf break (1000 to 3000 $\mathrm{m})$, and neritic $(<1000 \mathrm{~m})$ environments (Prince et al. 1999, Waugh et al. 1999). However, we wanted to discriminate between continental shelf breaks and shallower coastal regions characterized by predictable tidal fronts. Both are highly productive regions exploited by marine birds, but they sustain distinct food-webs mediated by different physical processes (Schneider et al. 1986, Springer et al. 1996).

Albatross habitat use patterns. We integrated the telemetry environmental data using the ArcView 3.1 Geographic Information System (ESRI Inc., Redlands, CA). More specifically, we overlaid the telemetry tracks on maps of bathymetry and concurrent ocean temperature and chlorophyll concentration. Next, we calculated how much time the tracked albatrosses spent over specific water masses, productivity regimes, and depth domains, assuming that the birds moved in a straight line and flew at a constant speed between consecutive satellite fixes (Waugh et al. 1999).

To circumvent potential biases caused by the differential satellite coverage as a function of latitude, habitat use was quantified as the proportion of 'albatross hours' allocated to each specific ocean habitat, instead of the number of satellite locations. For $1 \mathrm{~d}$ of transmissions at 30 and $45^{\circ}$ latitude, we would expect an average of 9 and 11 satellite locations respectively (Argos 1989). Therefore, habitat-use metrics based on the number of satellite locations in different geographic areas would overestimate the importance of high latitude regions. It is unlikely that the habitat-use metrics based on the spatial distributions of 'albatross hours' would be subject to similar biases because the time intervals between successive satellite fixes did not vary significantly across latitude (Simple linear regression; $F_{1,2744}=3.082, \mathrm{p}=0.149$ ).

We contrasted the oceanic habitats (SST, chl a, seafloor depth) occupied by foraging albatrosses during the brooding and rearing periods using 2 complementary approaches. First, we compared the habitats used by individual birds that had been tracked during both periods of the breeding cycle (12 birds and 82 foraging trips, Table 1). This was the most conservative analysis because it was restricted to a paired comparison of foraging trips taken by the same individuals during the 2 distinct periods. We used a repeated measures analysis of variance (ANOVA) to determine whether species, gender, and breeding period influenced the oceanographic habitats occupied by foraging albatrosses.

Next, we performed the same analysis using a larger data set including birds that were tracked during only 1 period of the breeding cycle. Therefore, this analysis was subject to potential artifacts related to the random inclusion of birds with distinct habitat use patterns during only 1 period of the breeding cycle. We used generalized linear models (GLMs) to determine whether the oceanic habitats occupied by individual birds varied significantly across species, genders, and periods of the breeding cycle. These models also allowed us to test for interactions between these 3 factors, and for differences across individuals. These comparisons included all the data collected during this study (29 birds and 131 foraging trips, Table 1). We tested all ANOVA, GLM and ANCOVA residuals for normality using Kolmogorov-Smirnov tests (Zar 1984), and performed all statistical analyses using the Systat 7.0 software package (Wilkinson 1997). All residuals were normally distributed $(\mathrm{p}>0.05$ for all comparisons).

Albatross foraging behavior. Satellite telemetry can delineate the locations where far-ranging seabirds forage (Jouventin \& Weimerskirch 1990, Veit \& Prince 1997, Prince et al. 1999, Gonzalez-Solis et al. 2000). More specifically, the rate of movement of satellite tracked albatrosses has been used to study their foraging behavior during different periods of the day, and within specific oceanic regions (Jouventin \& Weimerskirch 1990, Sagar \& Weimerskirch 1996, Stahl \& Sagar 2000a, Fernández et al. 2001). Behavioral observations from survey vessels suggest that foraging seabirds turn more frequently when they encounter dense prey concentrations (Veit \& Prince 1997, Nevitt \& Veit 1999, Veit 1999). In particular, the flight speed and the immersion rate of black-footed and Laysan albatrosses are negatively correlated, validating the assumption that slow movements are indicative of foraging activity in these species (Fernández \& Anderson 2000). Thus, we equated albatross searching behavior with slow and highly contorted telemetry tracks, and interpreted rapid and directional flight as directed transit between the breeding colony and foraging grounds (Cherel \& Weimerskirch 1995, Rodhouse et al. 1996, Sagar \& 
Weimerskirch 1996, Anderson et al. 1998, Prince et al. 1999).

To determine whether foraging albatrosses searched continuously or commuted to specific feeding grounds, we compared the behavior of the satellite-tracked birds during different stages of their foraging trips. We analyzed 131 complete forays taken by 29 albatrosses, and considered 3 different stages: outbound commute, feeding, and inbound commute. We arbitrarily divided foraging trips into 3 parts of equal duration and compared the movement rate (speed) of the tracked birds and the directionality of their trajectories during these distinct stages. If the birds foraged continuously, we anticipated no significant differences in the directionality of their tracks and their rate of movement. On the other hand, if albatrosses commuted to specific foraging areas, they should behave differently during the commuting and the feeding parts of foraging trips. Specifically, we predicted that albatrosses would move in a rapid and directed fashion during the outbound and inbound commutes, when they were not searching for prey. Conversely, if birds engaged in area restricted searching behavior or sat on the water to feed, their net movement rate should decrease in areas of high prey concentrations.

This analysis was restricted to high quality (Argos Class A or better) satellite locations separated by more than 1 and less than 8 h. Moreover, we considered only those foraging trips with at least 3 high quality tracks during each of the 3 stages. For each of the 59 foraging trips that met these requirements, we calculated the net movement rate (speed) between successive satellite locations assuming that the birds traveled in a straight line, and computed the median and maximum movement rate for the 3 stages (outbound, feeding, inbound) of every foraging trip. We also used the coefficient of concentration $(r$ ) to assess the directionality of the telemetry tracks (Klimley 1993). This index ranges between 0 and 1 and is calculated as follows (Zar 1984):

$$
\begin{aligned}
X & =\sum \cos \left(h_{i}\right) / \mathrm{n} \\
Y & =\sum \sin \left(h_{i}\right) / \mathrm{n} \\
r & =\left(X^{2}+Y^{2}\right)^{1 / 2}
\end{aligned}
$$

Where $h_{i}$ are the albatross headings, and $X$ and $Y$ are the average cosine and sine respectively. The coefficient of concentration is related to the circular variance $\left(s^{2}=1-r\right)$. When $r=1$, the headings are highly concentrated and the circular variance is equal to 0 . Conversely, when $r=0$, the headings are dispersed and the circular variance equals 1 .

We used a repeated measures analysis of covariance (ANCOVA) to compare albatross movement rates (median and maximum speed) and directionality (index of concentration) during the outbound, feeding, and inbound stages of foraging trips. We grouped the foraging trips by gender and species, and tested for individual effects using each tracked bird as a covariate (Zar 1984, Wilkinson 1997). Moreover, because the statistics used to characterize albatross movements are likely to be sample size dependent, we determined if there were differences in the number of observations across stages, individual birds, genders and species to detect possible biases in the data.

Albatross foraging areas. We employed kernel estimation techniques to delineate the foraging ranges and the core habitat areas used by both albatross species and genders during the brooding and rearing periods (Prince et al. 1999, Gonzalez-Solis et al. 2000, Wood et al. 2000). We performed these analyses using the animal movement extension to the Arcview GIS software package (Hooge \& Eichenlaub 1997), available at the Alaska Biological Science Center website (www.absc.usgs.gov/glba/gistools/). We employed the fixed kernel approach (Worton 1989) and the least squares smoothing algorithm recommended by Seaman \& Powell (1996). We arbitrarily chose 3 activity ranges to depict black-footed and Laysan albatross dispersion at sea (Gonzalez-Solis et al. 2000, Wood et al. 2000). These activity ranges were delineated by the $95 \%$ (foraging range), $50 \%$ (focal region), and $25 \%$ (core area) isopleths of the cumulative time at sea ('albatross hours') distributions.

To assess the degree of spatial segregation of albatross distributions, we quantified the overlap of the activity ranges for birds of different species and genders during the brooding and rearing periods of the breeding season. We considered the overlap at 2 activity levels corresponding to the marine range (95\% time at sea) and the core foraging areas $(25 \%$ time at sea). We quantified overlap as the proportional time that individuals of the various species/genders spent within each other's activity ranges. Therefore, overlap metrics ranged from 0 (no time spent within activity range) to 1 (all time at sea spent within activity range). Moreover, because overlap is not necessarily symmetrical, we calculated 2 indices for each pair-wise comparison (Gonzalez-Solis et al. 2000, Wood et al. 2000).

\section{RESULTS}

\section{Albatross habitats}

Black-footed and Laysan albatrosses exploited different habitats during the brooding and rearing periods (Tables 2 \& 3). Brooding albatrosses were largely restricted to pelagic (depth: $>3000 \mathrm{~m}$ ), oligotrophic (chl a: $<0.1 \mathrm{mg} \mathrm{m}^{-3}$ ), tropical waters (SST: 
$>20^{\circ} \mathrm{C}$ ). Conversely, during the rearing period, both species ranged over highly productive (chl a: $>0.3 \mathrm{mg}$ $\mathrm{m}^{-3}$ ) and cooler Transition Domain and Subarctic Domain waters (SST: $<15^{\circ} \mathrm{C}$ ) in pelagic and neritic environments (Figs. 2, 3 \& 4).

During the brooding period, black-footed albatross foraged predominantly over pelagic waters (depth: $>3000 \mathrm{~m})$, and along slope (1000 to $3000 \mathrm{~m})$ and shelf areas (200 to $1000 \mathrm{~m})$ in the vicinity of Tern Island (Table 2, Figs. 4 \& 5). Moreover, brooding black-footed albatross were largely restricted to warm, low productivity tropical waters, where they spent most of their time at sea (Fig. 2). Although some birds ventured into the mesotrophic waters of the Transition Zone Chlorophyll Front (chl a: 0.1 to
$0.3 \mathrm{mg} \mathrm{m}^{-3}$ ), brooding black-footed albatross spent 75 to $80 \%$ of the time at sea over oligotrophic waters with low chlorophyll concentrations (chl $a$ : $<0.1 \mathrm{mg}$ $\mathrm{m}^{-3}$ ) (Fig. 3). During the rearing period, black-footed albatrosses traveled to distant continental shelves and coastal regions (Figs. 4 \& 5). Five of the 6 females and 1 of the 2 males tracked during this period commuted to the continental shelf of North America from 34 to $48^{\circ} \mathrm{N}$ (central California to British Columbia). These long foraging trips were mixed with shorter forays to low productivity, tropical waters (SST: $>20^{\circ} \mathrm{C}$ ) close to Tern Island (Fernández et al. 2001). Overall, rearing male and female blackfooted albatross spent 14 and $22 \%$ their time at sea over highly productive waters ( $\mathrm{chl} a$ : $>0.3 \mathrm{mg} \mathrm{m}^{-3}$ ).

Table 2. Descriptive statistics of female and male black-footed albatross habitats during the brooding and rearing periods. $\tilde{X}_{\mathrm{t}}$ : median of all trips; $\widetilde{X}_{\mathrm{b}}$ : median of all birds calculated using the median values of each individual bird as data points

\begin{tabular}{|c|c|c|c|c|c|c|c|}
\hline \multirow[t]{2}{*}{ Gender } & \multirow{2}{*}{$\begin{array}{c}\text { Period } \\
\text { (chick age, } \\
\text { days) }\end{array}$} & \multicolumn{2}{|c|}{$\begin{array}{l}\text { Sea surface temperature } \\
\qquad\left({ }^{\circ} \mathrm{C}\right)\end{array}$} & \multicolumn{2}{|c|}{$\begin{array}{l}\text { Chlorophyll concentration } \\
\left(\mathrm{mg} \mathrm{chl} a \mathrm{~m}^{-3}\right)\end{array}$} & \multicolumn{2}{|c|}{$\begin{array}{l}\text { Seafloor depth } \\
\text { (m) }\end{array}$} \\
\hline & & $\begin{array}{c}\tilde{x}_{\mathrm{t}} \\
(\max -\min ) \\
\mathrm{n}\end{array}$ & $\begin{array}{c}\tilde{x}_{\mathrm{b}} \\
(\max -\min ) \\
\mathrm{n}\end{array}$ & $\begin{array}{c}\tilde{x}_{\mathrm{t}} \\
(\max -\min ) \\
\mathrm{n}\end{array}$ & $\begin{array}{c}\tilde{x}_{\mathrm{b}} \\
(\max -\min ) \\
\mathrm{n}\end{array}$ & $\begin{array}{c}\tilde{x}_{\mathrm{t}} \\
(\max -\min ) \\
\mathrm{n}\end{array}$ & $\begin{array}{c}\tilde{x}_{\mathrm{b}} \\
(\max -\min ) \\
\mathrm{n}\end{array}$ \\
\hline \multirow[t]{2}{*}{ Female } & $\begin{array}{l}\text { Brooding } \\
(0-18)\end{array}$ & $\begin{array}{c}22.4 \\
(24.1-20.7) \\
24\end{array}$ & $\begin{array}{c}22.4 \\
(23.2-22.1) \\
6\end{array}$ & $\begin{array}{c}0.08 \\
(0.12-0.07) \\
24\end{array}$ & $\begin{array}{c}0.08 \\
(0.09-0.08) \\
6\end{array}$ & $\begin{array}{c}4374.7 \\
(5001-1335) \\
24\end{array}$ & $\begin{array}{c}4144 \\
(4707.5-2595.5) \\
6\end{array}$ \\
\hline & $\begin{array}{l}\text { Rearing } \\
(19-140)\end{array}$ & $\begin{array}{c}21.6 \\
(24.8-12.1) \\
30\end{array}$ & $\begin{array}{c}18.8 \\
(23.7-12.6) \\
6\end{array}$ & $\begin{array}{c}0.10 \\
(0.28-0.07) \\
30\end{array}$ & $\begin{array}{c}0.13 \\
(0.27-0.08) \\
6\end{array}$ & $\begin{array}{c}4402 \\
(6233-202) \\
30\end{array}$ & $\begin{array}{c}4059 \\
(4791-3679) \\
6\end{array}$ \\
\hline \multirow[t]{2}{*}{ Male } & $\begin{array}{l}\text { Brooding } \\
(0-18)\end{array}$ & $\begin{array}{c}22.8 \\
(23.9-22.2) \\
16\end{array}$ & $\begin{array}{c}22.9 \\
(23.4-22.6) \\
6\end{array}$ & $\begin{array}{c}0.08 \\
(0.09-0.06) \\
16\end{array}$ & $\begin{array}{c}0.08 \\
(0.09-0.07) \\
6\end{array}$ & $\begin{array}{c}3983.5 \\
(5016-1784) \\
16\end{array}$ & $\begin{array}{c}4018 \\
(4279-2878) \\
6\end{array}$ \\
\hline & $\begin{array}{l}\text { Rearing } \\
(19-140)\end{array}$ & $\begin{array}{c}21.9 \\
(23.3-17.9) \\
7\end{array}$ & $\begin{array}{c}22.1 \\
(22.5-21.7) \\
2\end{array}$ & $\begin{array}{c}0.09 \\
(0.14-0.07) \\
7\end{array}$ & $\begin{array}{c}0.09 \\
(0.09-0.08) \\
2\end{array}$ & $\begin{array}{c}4177 \\
(6566-369) \\
7\end{array}$ & $\begin{array}{c}3505 \\
(4640-2370) \\
2\end{array}$ \\
\hline
\end{tabular}

Table 3. Descriptive statistics of female and male Laysan albatross habitats during the brooding and rearing periods. $\widetilde{x}_{\mathrm{t}}:$ median of all trips; $\widetilde{x}_{\mathrm{b}}$ : median of all birds calculated using the median values of each individual bird as data points

\begin{tabular}{|c|c|c|c|c|c|c|c|}
\hline \multirow[t]{2}{*}{ Gender } & \multirow{2}{*}{$\begin{array}{c}\text { Period } \\
\text { (chick age, } \\
\text { days) }\end{array}$} & \multicolumn{2}{|c|}{$\begin{array}{c}\text { Sea surface temperature } \\
\left({ }^{\circ} \mathrm{C}\right)\end{array}$} & \multicolumn{2}{|c|}{ 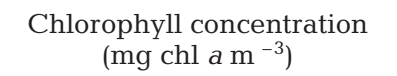 } & \multicolumn{2}{|c|}{$\begin{array}{l}\text { Seafloor depth } \\
(\mathrm{m})\end{array}$} \\
\hline & & $\begin{array}{c}\tilde{x}_{\mathrm{t}} \\
(\max -\min ) \\
\mathrm{n}\end{array}$ & $\begin{array}{c}\tilde{x}_{\mathrm{b}} \\
(\max -\min ) \\
\mathrm{n}\end{array}$ & $\begin{array}{c}\tilde{X}_{t} \\
(\max -\min ) \\
\mathrm{n}\end{array}$ & $\begin{array}{c}\tilde{x}_{\mathrm{b}} \\
(\max -\min ) \\
\mathrm{n}\end{array}$ & $\begin{array}{c}\tilde{x}_{t} \\
(\max -\min ) \\
n\end{array}$ & $\begin{array}{c}\tilde{x}_{\mathrm{b}} \\
(\max -\min ) \\
\mathrm{n}\end{array}$ \\
\hline \multirow[t]{2}{*}{ Female } & $\begin{array}{l}\text { Brooding } \\
\quad(0-18)\end{array}$ & $\begin{array}{c}22.7 \\
(23.9-7.5) \\
17\end{array}$ & $\begin{array}{c}22.4 \\
(23.4-13.1) \\
6\end{array}$ & $\begin{array}{c}0.08 \\
(0.25-0.06) \\
17\end{array}$ & $\begin{array}{c}0.08 \\
(0.24-0.08) \\
6\end{array}$ & $\begin{array}{c}4095 \\
(5667-1958) \\
17\end{array}$ & $\begin{array}{c}4362 \\
(5369-2152) \\
6\end{array}$ \\
\hline & $\begin{array}{l}\text { Rearing } \\
(19-140)\end{array}$ & $\begin{array}{c}11.8 \\
(23.9-6.6) \\
10\end{array}$ & $\begin{array}{c}17.6 \\
(8.8-6.7) \\
3\end{array}$ & $\begin{array}{c}0.22 \\
(0.34-0.07) \\
10\end{array}$ & $\begin{array}{c}0.16 \\
(0.32-0.28) \\
3\end{array}$ & $\begin{array}{c}3772 \\
(4621-238) \\
10\end{array}$ & $\begin{array}{c}3772 \\
(4106-196) \\
3\end{array}$ \\
\hline \multirow[t]{2}{*}{ Male } & $\begin{array}{l}\text { Brooding } \\
(0-18)\end{array}$ & $\begin{array}{c}21.3 \\
(23.3-12.4) \\
15\end{array}$ & $\begin{array}{c}21.3 \\
(22.9-20) \\
6\end{array}$ & $\begin{array}{c}0.15 \\
(0.26-0.08) \\
15\end{array}$ & $\begin{array}{c}0.12 \\
(0.19-0.08) \\
6\end{array}$ & $\begin{array}{c}4785 \\
(5375-2154) \\
15\end{array}$ & $\begin{array}{c}4702 \\
(4955-3650) \\
6\end{array}$ \\
\hline & $\begin{array}{l}\text { Rearing } \\
(19-140)\end{array}$ & $\begin{array}{c}7.9 \\
(23.5-4.8) \\
12\end{array}$ & $\begin{array}{c}6.9 \\
(16.9-6.4) \\
4\end{array}$ & $\begin{array}{c}0.24 \\
(0.33-0.07) \\
12\end{array}$ & $\begin{array}{c}0.25 \\
(0.27-0.06) \\
4\end{array}$ & $\begin{array}{c}4078 \\
(5725-1367) \\
12\end{array}$ & $\begin{array}{c}4040 \\
(4401-3003) \\
4\end{array}$ \\
\hline
\end{tabular}




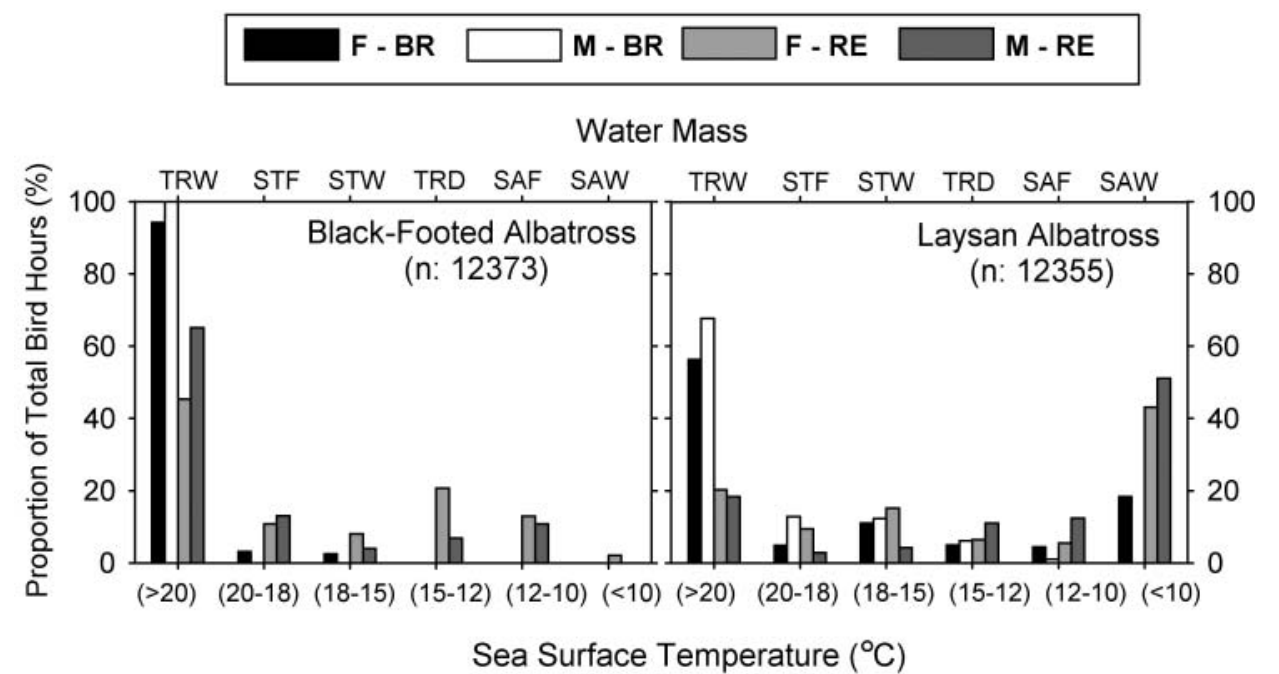

Sea Surface Temperature $\left({ }^{\circ} \mathrm{C}\right)$
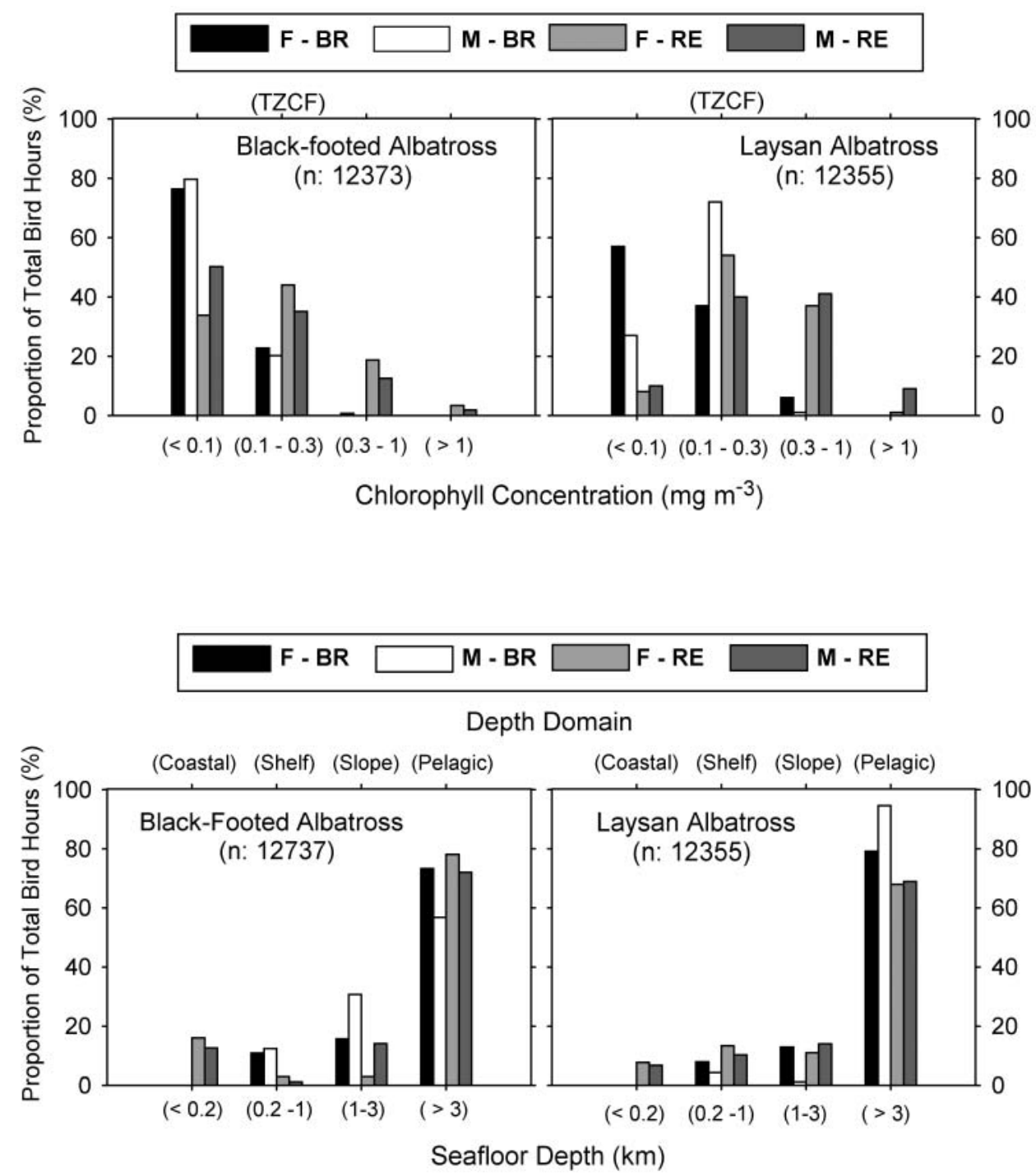

Fig. 2. Proportion of time satellite tracked male (M) and female (F) black-footed and Laysan albatrosses spent in different water masses during the brooding (BR) and rearing (RE) periods. Water masses were defined using weekly sea surface temperature satellite imagery. n: number of $30 \mathrm{~min}$ bins used in this analysis

Fig. 3. Proportion of time satellite tracked male (M) and female (F) black-footed and Laysan albatrosses spent in regions of different ocean productivity during the brooding (BR) and rearing (RE) periods. Ocean productivity was quantified using monthly SeaWiFS imagery of chlorophyll concentrations. n: number of $30 \mathrm{~min}$ bins used in this analysis

Fig. 4. Proportion of time satellite tracked male $(\mathrm{M})$ and female (F) black-footed and Laysan albatrosses spent in different bathymetric domains during the brooding (BR) and rearing (RE) periods. Depth domains were defined using GEBCO digital bathymetric charts. n: number of $30 \mathrm{~min}$ bins used in this analysis 


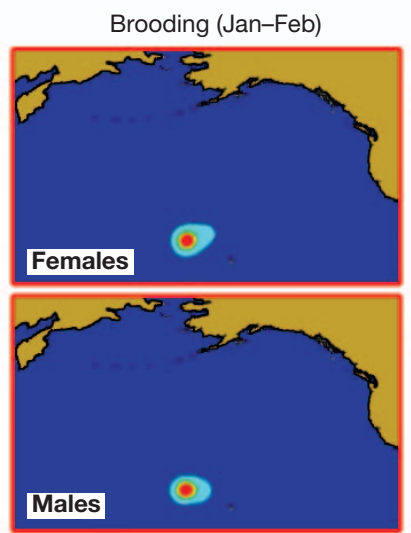

Proportion of total albatross hours:

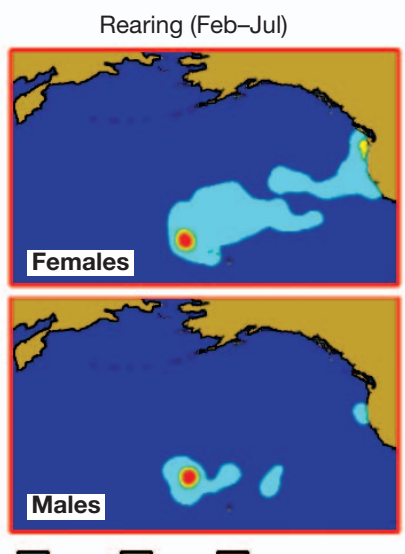

$995 \% \square 50 \% \square 25 \%$

Fig. 5. Density contour plots from kernel estimates of the amount of time female and male black-footed albatross spent at sea during the brooding and rearing periods. Densities corresponding to 3 activity levels are considered: $95 \%$ (foraging range), $50 \%$ (focal region), and $25 \%$ (core area)

Moreover, approximately 13 and $16 \%$ of their time at sea was spent foraging in shallow (depth: $<200 \mathrm{~m}$ ) coastal regions (Fig. 4).

Laysan albatross occasionally ventured into cooler and productive Transition Domain and Subarctic waters during the brooding period, though they largely ranged over warm (SST: $>18^{\circ} \mathrm{C}$ ) tropical and subtropical waters in the vicinity of Tern Island (Table 3, Figs. 2, 3 \& 6). Brooding Laysan albatross ranged predominantly over deep water $(>3000 \mathrm{~m})$, and spent a considerable amount of their time at sea ( $37 \%$ for females and $72 \%$ for males) in the vicinity of the Transition Zone Chlorophyll Front (chl a: 0.1 to $0.3 \mu \mathrm{g} \mathrm{chl}$ a $\mathrm{m}^{-3}$ ) (Figs. $3 \& 4$ ). During the rearing period, both genders mixed long $(>12 \mathrm{~d})$ and short $(<6 \mathrm{~d})$ foraging trips (Fernández et al. 2001) and ranged into cool and highly productive subarctic waters (SST: $<10^{\circ} \mathrm{C}$ ) (Figs. $2 \& 3$ ). Long foraging trips reached the North Pacific Transition Domain (TRD) and the Aleutian Chain (Fig. 6). During short trips, Laysan albatrosses foraged over low productivity, tropical waters close to Tern Island (Table 3, Fernández et al. 2001).

The repeated measures ANOVA revealed that the same individual birds foraged over waters of different sea surface temperature and chlorophyll concentration during the brooding and rearing periods. This test also detected speciesspecific differences in the sea surface
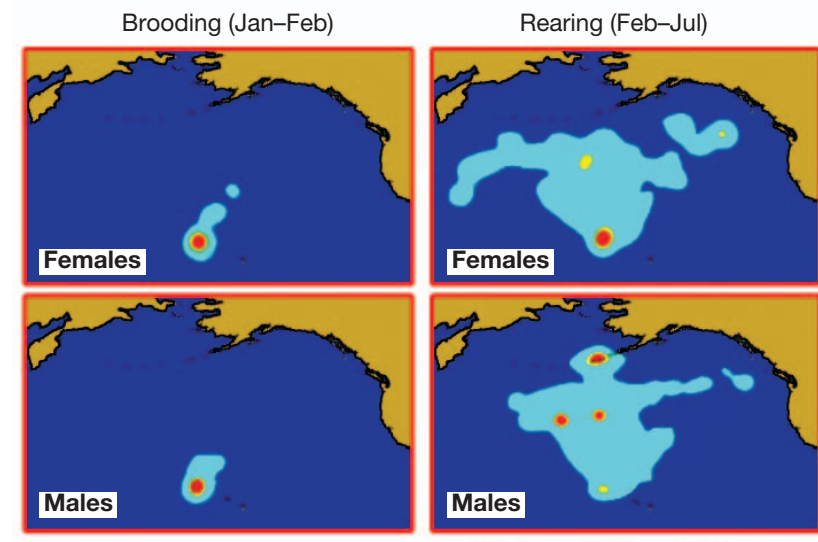

Proportion of total albatross hours:

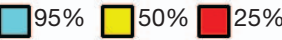

Fig. 6. Density contour estimates from kernel estimates of the amount of time Laysan albatross spent at sea during the brooding and rearing periods. Densities corresponding to 3 activity levels are considered: 95\% (foraging range), 50\% (focal region), and $25 \%$ (core area)

temperature and depth domains used during the brooding and rearing periods (Table 4). GLM results supported the notion that brooding and rearing albatrosses foraged over different water masses and ocean productivity domains. Moreover, this test revealed significant differences in the sea surface temperature and chlorophyll concentration experienced by blackfooted and Laysan albatrosses (Table 5).

Table 4. Results of the analysis of individual albatross habitat use patterns using a repeated measures ANOVA. Bold denotes significant results

\begin{tabular}{|c|c|c|c|c|c|}
\hline \multirow{2}{*}{$\begin{array}{l}\text { Trial Factor: } \\
\text { Grouping Factor 1: } \\
\text { Grouping Factor 2: } \\
\text { Source }\end{array}$} & \multicolumn{5}{|c|}{$\begin{array}{l}\text { Period (brooding/rearing) } \\
\text { Species (black-footed/Laysan) } \\
\text { Gender (female/male) }\end{array}$} \\
\hline & SS & df & MS & $F$ & $\mathrm{p}$ \\
\hline \multicolumn{6}{|l|}{ (A) Median temperature } \\
\hline Period & 156.029 & 1 & 156.029 & 17.917 & 0.004 \\
\hline Period $\times$ Species & 56.244 & 1 & 56.244 & 6.458 & 0.038 \\
\hline Period $\times$ Gender & 2.477 & 1 & 2.477 & 0.284 & 0.610 \\
\hline Period $\times$ Species $\times$ Gender & 40.791 & 1 & 40.791 & 4.684 & 0.067 \\
\hline Error & 60.958 & 7 & & & \\
\hline \multicolumn{6}{|c|}{ (B) Median chlorophyll concentration } \\
\hline Period & 0.0203 & 1 & 0.0203 & 9.975 & 0.016 \\
\hline Period $\times$ Species & 0.0017 & 1 & 0.0017 & 0.860 & 0.384 \\
\hline Period $\times$ Gender & 0.0004 & 1 & 0.0004 & 0.191 & 0.675 \\
\hline Period $\times$ Species $\times$ Gender & 0.0033 & 1 & 0.0033 & 1.605 & 0.245 \\
\hline Error & 0.0143 & 7 & 0.0020 & & \\
\hline \multicolumn{6}{|l|}{ (C) Median seafloor depth } \\
\hline Period & 1.005 E 6 & 1 & 1.005 e 6 & 1.893 & 0.211 \\
\hline Period $\times$ Species & 4.782 E 6 & 1 & 4.782 e 6 & 9.007 & 0.019 \\
\hline Period $\times$ Gender & 1.442 E 6 & 1 & 1.442 e 6 & 2.716 & 0.143 \\
\hline Period $\times$ Species $\times$ Gender & 0.018 E 6 & 1 & 0.018 e 6 & 0.034 & 0.857 \\
\hline Error & 3.71 E 6 & 7 & 0.531 e 6 & & \\
\hline
\end{tabular}


Table 5. Results of the analysis of albatross habitat use patterns with GLMs. The data were blocked by individual bird for analysis. Bold denotes significant results

\begin{tabular}{|lccc|}
\hline Factor & df & $F$ & $\mathrm{p}$ \\
\hline (A) Median sea surface temperature & & \\
Block & 28 & 0.637 & 0.835 \\
Period & $\mathbf{1}$ & $\mathbf{2 1 . 3 9 0}$ & $<\mathbf{0 . 0 0 0 1}$ \\
Gender & 1 & 0.025 & 0.8751 \\
Species & $\mathbf{1}$ & $\mathbf{7 . 7 2 7 5}$ & $\mathbf{0 . 0 0 8}$ \\
Gender $\times$ Period & 1 & 0.146 & 0.705 \\
Species $\times$ Period & 1 & 1.359 & 0.251 \\
Species $\times$ Gender & 1 & 0.349 & 0.558 \\
Species $\times$ Gender $\times$ Period & 1 & 0.819 & 0.371 \\
(B) Median chlorophyll concentration & & \\
Block & 28 & 1.071 & 0.475 \\
Period & $\mathbf{1}$ & $\mathbf{1 5 . 9 2}$ & $\mathbf{0 . 0 0 0 3}$ \\
Gender & 1 & 0.216 & 0.645 \\
Species & $\mathbf{1}$ & $\mathbf{8 . 6 5 9}$ & $\mathbf{0 . 0 0 5}$ \\
Gender $\times$ Period & 1 & 0.158 & 0.693 \\
Species $\times$ Period & 1 & 0.058 & 0.810 \\
Species $\times$ Gender & 1 & 0.349 & 0.558 \\
Species $\times$ Gender $\times$ Period & 1 & 0.280 & 0.599 \\
(C) Seafloor depth & & & \\
Block & 28 & 1.138 & 0.429 \\
Period & 1 & 0.190 & 0.665 \\
Gender & 1 & 1.160 & 0.288 \\
Species & 1 & 0.001 & 0.982 \\
Gender $\times$ Period & 1 & 2.904 & 0.097 \\
Species $\times$ Period & 1 & 0.157 & 0.694 \\
Species $\times$ Gender & 1 & 0.005 & 0.945 \\
Species $\times$ Gender $\times$ Period & 1 & 0.063 & 0.804 \\
\hline
\end{tabular}

\section{Albatross foraging behavior}

Analyses of the rate of movement (speed) and the directionality of telemetry tracks revealed that albatrosses changed their behavior during different parts of their foraging excursions. The satellite-tracked albatrosses moved faster and in a more directed fashion during the outbound (first third) and the inbound (last third) commuting stages of foraging trips. During the middle part of their forays, the birds moved more slowly and described highly erratic trajectories (Fig. 7). A repeated measures ANCOVA revealed that the observed differences in flight speed and track directionality were only significant across stages of foraging trips. Conversely, we detected no significant differences across species, gender and individual birds, suggesting that albatrosses of both genders and species engage in a similar foraging behavior during trips to sea (Table 6).

Additional tests relating the movement rate (speed) and the contortion of the telemetry tracks indicated that albatrosses employ distinct searching strategies while commuting to and from foraging areas. During the outbound transit, the median movement rate and the coefficient of heading concentration ( $r$ ) were not significantly correlated (Spearman Rank Test, $\mathrm{R}_{\mathrm{s}}=$ $0.034, \mathrm{n}=59, \mathrm{p}>0.5)$. Conversely, the directionality of
Table 6 . Results of the analysis of albatross foraging behavior using repeated measures ANCOVA. Bold denotes significant results

\begin{tabular}{|c|c|c|c|c|c|}
\hline \multirow{2}{*}{$\begin{array}{l}\text { Trial Factor: } \\
\text { Grouping Factor 1: } \\
\text { Grouping Factor 2: } \\
\text { Factor }\end{array}$} & \multicolumn{5}{|c|}{$\begin{array}{l}\text { Stage (outbound/feeding/inbound) } \\
\text { Species (black-footed/Laysan) } \\
\text { Gender (females/males) }\end{array}$} \\
\hline & SS & df & MS & $F$ & $\mathrm{p}$ \\
\hline \multicolumn{6}{|l|}{ (A) Sample size } \\
\hline Stage & 13.214 & 2 & 6.607 & 0.474 & 0.624 \\
\hline Stage $\times$ Species & 14.422 & 2 & 7.211 & 0.517 & 0.597 \\
\hline Stage $\times$ Gender & 11.200 & 2 & 5.600 & 0.402 & 0.670 \\
\hline Stage $\times$ Species $\times$ Gende & er 42.440 & 2 & 21.220 & 1.523 & 0.223 \\
\hline Stage $\times$ Bird & 30.566 & 2 & 15.283 & 1.096 & 0.322 \\
\hline Error & 1504.965 & 108 & 13.935 & & \\
\hline \multicolumn{6}{|c|}{ (B) Coefficient of concentration } \\
\hline Stage & 0.458 & 2 & 0.229 & 7.434 & $<0.001$ \\
\hline Stage $\times$ Species & 0.074 & 2 & 0.037 & 1.201 & 0.305 \\
\hline ender & 0.083 & 2 & 0.041 & 1.347 & 0.264 \\
\hline Stage $\times$ Species $\times$ Gende & er 0.033 & 2 & 0.016 & 0.536 & 0.586 \\
\hline Stage $\times$ Bird & 0.059 & 2 & 0.029 & 0.971 & 0.382 \\
\hline Error & 3.332 & 108 & 0.031 & & \\
\hline \multicolumn{6}{|l|}{ (C) Median speed } \\
\hline Stag & 789.862 & 2 & 394.931 & 4.465 & 0.014 \\
\hline Stage $\times$ Species & 105.180 & 2 & 52.590 & 0.594 & 0.553 \\
\hline Stage $\times$ Gender & 29.655 & 2 & 14.827 & 0.167 & 0.846 \\
\hline Stage $\times$ Species $\times$ Gende & er 91.796 & 2 & 45.898 & 0.519 & 0.596 \\
\hline Stage $\times$ Bird & 157.731 & 2 & 78.865 & 0.891 & 0.413 \\
\hline Error & 9553.019 & 108 & 88.454 & & \\
\hline \multicolumn{6}{|l|}{ (D) Maximum speed } \\
\hline Stag & 1279.145 & 2 & 639.572 & 3.100 & 0.049 \\
\hline Stage $\times$ Species & 37.119 & 2 & 18.559 & 0.089 & 0.914 \\
\hline Stage $\times$ Gender & 29.655 & 2 & 717.283 & 1.738 & 0.180 \\
\hline Stage $\times$ Species $\times$ Gende & er 511.326 & 2 & 255.663 & 1.239 & 0.293 \\
\hline Stage $\times$ Bird & 433.414 & 2 & 216.707 & 1.050 & 0.353 \\
\hline Error & 22280.032 & 108 & 206.296 & & \\
\hline
\end{tabular}

the telemetry tracks and the net movement rates were positively correlated during the feeding (Spearman $\mathrm{R}_{\mathrm{s}}=0.304, \mathrm{n}=59,0.02>\mathrm{p}>0.01$ ) and the inbound (Spearman $\mathrm{R}_{\mathrm{s}}=0.257, \mathrm{n}=59, \mathrm{p}=0.05$ ) stages. Thus, during the middle and ending parts of foraging trips, birds that traveled more slowly tended to follow more contorted paths. Conversely, a bird's net speed was not related to the complexity of its trajectory during the outbound stage of a foraging trip. These results suggest that albatrosses commuted rapidly to foraging areas (outbound commute), foraged at those localities (feeding stage), and continued to search for prey during their rapid return to the colony (inbound commute).

\section{Albatross foraging areas}

Contour plots of the amount of time satellite tracked birds spent at sea illustrated the distinct habitats used by brooding and rearing albatrosses, as well as gender-based and species-specific differences in foraging 

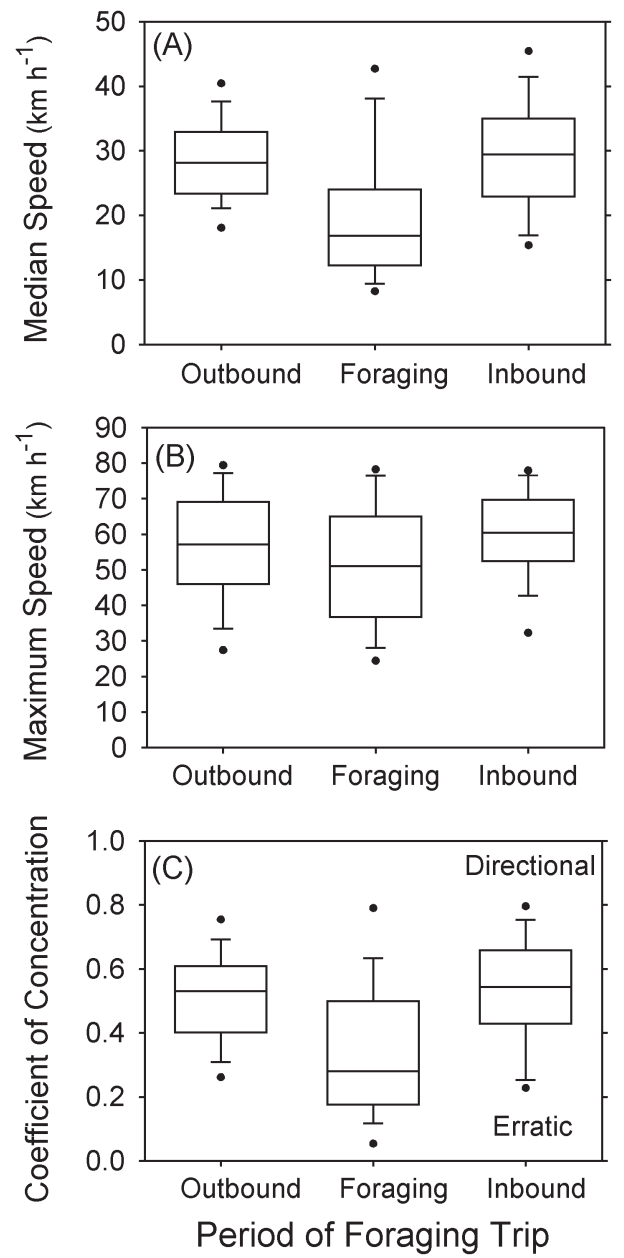

Fig. 7. The rate of movement (speed) and the directionality of albatross tracks changed during the beginning (outbound), middle (feeding), and ending (inbound) stages of foraging trips. Box plots depict the 5,10,25, 50, 75, 90 and 95 percentiles of the distributions of: (A) the median speed, (B) the maximum speed, and $(C)$ the coefficient of heading concentration (r). A total of 59 foraging trips from 28 albatrosses of both species and genders were analyzed

ranges and habitat use patterns (Figs. 5 \& 6). Brooding albatrosses were largely restricted to low latitude waters north of Tern Island $\left(23.878^{\circ} \mathrm{N}, 166.288^{\circ} \mathrm{W}\right)$, though Laysans had a more northern distribution. There was substantial overlap (55.90 to $85.25 \%$ ) between the foraging ranges ( $95 \%$ time at sea) and the core areas (25\% time at sea) of brooding black-footed and Laysan albatrosses (Table 7).

During the rearing period, foraging ranges expanded to include the waters of the California Current (black-footed albatross), the Gulf of Alaska (Laysan albatross) and the continental shelf along the Aleutians (Laysan albatross). Additionally, some of the rearing Laysan albatross ventured into the northwestern Pacific (west of $180^{\circ} \mathrm{W}$ ). The expansion of the foraging ranges diminished the overlap in albatross foraging ranges and core areas (Table 7 ). Mean overlap decreased significantly during the rearing stage, when both species and genders were considered (Wilcoxon test with normal approximation, $\mathrm{n}=8, Z=-2.521$, $\mathrm{p}=$ 0.012).

The kernel density contour plots also defined highuse areas where albatrosses concentrated their foraging activities (Figs. $5 \& 6$ ). These analyses revealed that, except in the vicinity of Tern Island, black-footed and Laysan albatross focal (50\% time at sea isopleth, delineated by the yellow contour) and core ( $25 \%$ time at sea isopleth, delineated by the red contour) activity areas did not overlap. Black-footed females focused their foraging along the continental shelf between California and British Columbia, while males foraged over a wider pelagic area (Fig. 5). Rearing Laysan albatross concentrated their foraging activities over pelagic waters along a broad band between latitude 38 and $50^{\circ} \mathrm{N}$. Female focal areas occurred in the Gulf of Alaska, and along the North Pacific Transition Domain. Conversely, Laysan albatross males spent most of their time at sea within the North Pacific Transition Domain and along the Aleutian shelf (Fig. 6).

The results of the kernel analyses can be interpreted more easily by including information on the foraging behavior of the satellite tracked birds. In particular, the disjunct foraging ranges depicted in

Table 7. Overlap of the activity ranges of black-footed and Laysan albatrosses during the brooding and rearing periods of the breeding season. Intraspecific and interspecific overlap is calculated for 2 activity levels: foraging ranges (95\% time at sea), and core areas (25\% time at sea). BFAL: black-footed albatross, LYAL: Laysan albatross. Overlap metrics range from 0 to $100 \%$

\begin{tabular}{|lcccccccc|}
\hline $\begin{array}{l}\text { Time } \\
\text { at sea }\end{array}$ & $\begin{array}{c}\text { Activity } \\
\text { range }\end{array}$ & \multicolumn{3}{c}{$\begin{array}{c}\text { Brooding period } \\
\text { Activity level } \\
95 \%\end{array}$} & $\begin{array}{c}\text { Mean } \\
25\end{array}$ & & \multicolumn{4}{c}{$\begin{array}{c}\text { Rearing period } \\
\text { Activity level } \\
25 \%\end{array}$} & $\begin{array}{c}\text { Mean } \\
25 \%\end{array}$ \\
\hline $\begin{array}{l}\text { BFAL } \\
\text { male }\end{array}$ & $\begin{array}{c}\text { BFAL } \\
\text { female }\end{array}$ & 98.69 & 71.30 & 85.00 & 85.87 & 15.64 & 50.76 \\
$\begin{array}{l}\text { BFAL } \\
\text { female }\end{array}$ & $\begin{array}{c}\text { BFAL } \\
\text { male }\end{array}$ & 94.38 & 72.69 & 83.54 & 39.87 & 1.83 & 20.85 \\
$\begin{array}{l}\text { LYAL } \\
\text { female }\end{array}$ & $\begin{array}{c}\text { LYAL } \\
\text { male }\end{array}$ & 69.90 & 41.90 & 55.90 & 71.29 & 0.45 & 35.87 \\
$\begin{array}{l}\text { LYAL } \\
\text { male }\end{array}$ & $\begin{array}{c}\text { LYAL } \\
\text { female }\end{array}$ & 91.87 & 49.56 & 70.72 & 64.35 & 3.88 & 34.12 \\
$\begin{array}{l}\text { BFAL } \\
\text { female }\end{array}$ & $\begin{array}{c}\text { LYAL } \\
\text { female }\end{array}$ & 66.75 & 45.05 & 55.90 & 36.36 & 12.16 & 24.26 \\
$\begin{array}{l}\text { BFAL } \\
\text { female }\end{array}$ & $\begin{array}{c}\text { LYAL } \\
\text { female }\end{array}$ & 92.68 & 77.82 & 85.25 & 27.22 & 8.78 & 18.00 \\
$\begin{array}{l}\text { LYAL } \\
\text { male }\end{array}$ & $\begin{array}{c}\text { BFAL } \\
\text { male } \\
\text { male }\end{array}$ & $\begin{array}{c}\text { LYAL } \\
\text { male }\end{array}$ & 92.69 & 55.56 & 74.13 & 12.50 & 0.91 & 6.71 \\
\hline
\end{tabular}


Figs. $5 \& 6$ become more intuitive when viewed in conjunction with flight speed data. The albatrosses tracked during this study largely traveled at speeds between 10 and $40 \mathrm{~km} \mathrm{~h}^{-1}$ (Fig. 8). Approximately 15 and $25 \%$ of the recorded movement rates were below $10 \mathrm{~km} \mathrm{~h}^{-1}$ and above $40 \mathrm{~km} \mathrm{~h}^{-1}$ respectively. Contour plots of movement rates during the rearing period revealed that albatrosses slowed down in specific areas associated with highly productive continental shelves (e.g. California to Washington State, Aleutian Chain), and water mass boundaries (e.g. North Pacific Transition Domain, California Current). For female black-footed albatross, slow speeds $(<10 \mathrm{~km}$ $\mathrm{h}^{-1}$ ) were observed off northern California, Oregon and Washington State, while faster speeds were recorded over pelagic waters between these shelf areas and Tern Island. Black-footed albatross males showed a similar pattern, with the slowest speeds along the eastern side of the basin and the fastest speeds over tropical waters northeast of the colony (Fig. 9). For Laysan albatross, the slowest speeds were recorded along the shelf of the Aleutians, and over pelagic waters between 38 and $50^{\circ} \mathrm{N}$. Conversely, Laysan albatross moved rapidly over low latitude $\left(23\right.$ to $\left.38^{\circ} \mathrm{N}\right)$ waters between Tern Island and the Transition Domain (Fig. 10).

\section{DISCUSSION}

We characterized the oceanic habitats used by 2 North Pacific albatross species breeding sympatrically on Tern Island, Hawaii, during the brooding and the

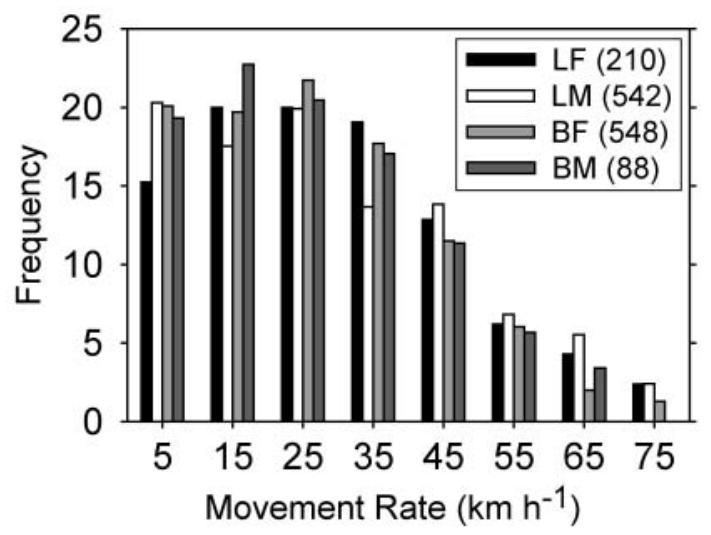

Fig. 8. Frequency distribution of albatross net movement rates (flight speeds) during the rearing period. Only high quality (Argos Class A or better) telemetry locations separated by $>1$ and $<8 \mathrm{~h}$ were included in this analysis. BF: black-foot female; BM: black-foot male; LF: Laysan female; LM: Laysan male. Sample size in parentheses
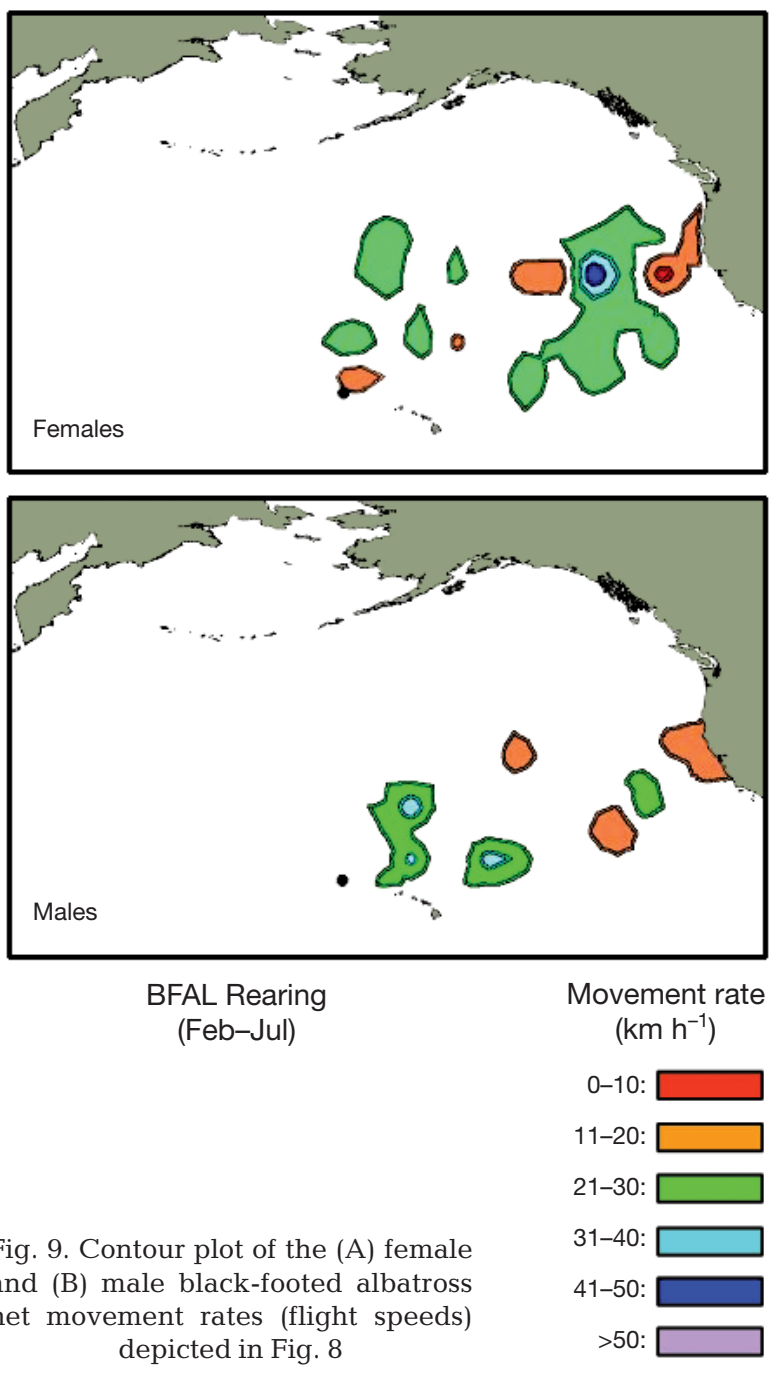

rearing periods of the reproductive cycle. The main objectives of this research were to determine whether these species use predictable habitats, and if so, to define the factors influencing their marine distributions.

Previously, marine ornithologists have documented that albatross dispersion patterns are influenced by reproductive duties at breeding colonies, prey dispersion, ocean productivity, and the distribution of physically distinct water masses (Stahl et al. 1985, Wahl et al. 1989, Veit \& Prince 1997, Weimerskirch et al. 1997, Prince et al. 1999, Stahl \& Sagar 2000a,b; Fernández et al. 2001). Because physical and biological variability in marine systems is scale dependent, we considered the significance of these processes at macro-mega scales (1000 to $3000 \mathrm{~km}$ ) and coarse-meso scales (10 to $100 \mathrm{~km}$ ) separately (Haury et al. 1978, Hunt \& Schneider 1987). 

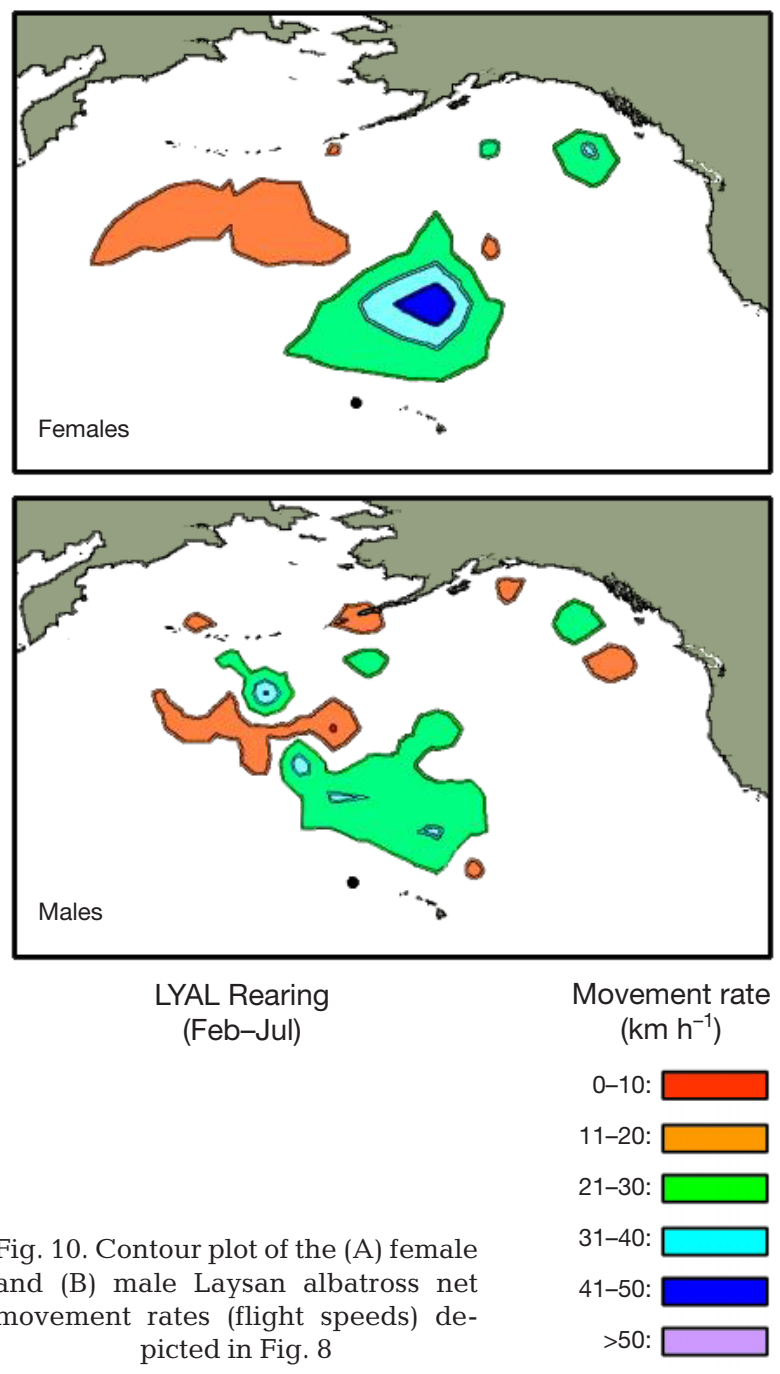

\section{Large-scale habitats: the role of water mass distributions}

Over macro-mega scales (1000 to $3000 \mathrm{~km}$ ), albatross distributions were mediated by large-scale ocean productivity patterns, influenced by water mass distributions, and constrained by breeding duties at the colony. Short foraging trips were most prevalent during the brooding period, when 1 parent tended the chick at the colony continuously (Fernández et al. 2001). Foraging ranges expanded with the onset of the rearing stage, when both parents foraged independently, leaving the chick unattended at the nest (Whittow 1993a,b). Rearing birds mixed long ( $>12 \mathrm{~d}$ ) forays to the California Current (black-footed albatross) and subarctic waters (Laysan albatross), with short (1 to 2 d) trips to tropical waters in the vicinity of the colony (Fernández et al. 2001). Moreover, the telemetry observations during the rearing period highlighted the broad marine distributions of the blackfooted and the Laysan albatross, including tropical, sub- tropical, and subarctic water masses (Figs. 2, 5 \& 6; Fernández et al. 2001). These results are consistent with previous vessel-based surveys and studies of high seas fisheries bycatch (Shuntov 1974, Gould 1983, Wahl et al. 1989, McKinnell \& Waddell 1993, Yatsu et al. 1993).

The observed differences in ranging behavior between the brooding and the rearing periods influenced the habitat-use patterns of breeding albatrosses. Brooding birds were largely restricted to pelagic (depth: $>3000 \mathrm{~m}$ ), oligotrophic ( $\mathrm{chl} \mathrm{a:}<0.3 \mathrm{mg} \mathrm{m}^{-3}$ ), warm (SST: $>20^{\circ} \mathrm{C}$ ) waters close to Tern Island. On the other hand, rearing birds ventured into cooler (SST: $<15^{\circ} \mathrm{C}$ ) and highly productive ( $\mathrm{chl} \mathrm{a:}>0.3 \mathrm{mg} \mathrm{m}^{-3}$ ), coastal waters (depth: <200 m) (Figs. 2, 3 \& 4). Disparities in the ranging behavior of incubating, brooding, and rearing albatrosses have been previously documented in Southern Ocean species such as the wandering albatross Diomedea exulans and the southern Buller's albatross D. bulleri bulleri (Prince et al. 1999, Stahl \& Sagar 2000 a,b). These differences have been ascribed to changing energetic requirements of the adults and their chicks during the breeding season (Weimerskirch et al. 1994a, 1997, Weimerskirch \& Cherel 1998).

Brooding black-footed and Laysan albatrosses probably engage in short trips to ensure a high and consistent rate of resource delivery to their chicks. Conversely, rearing birds probably venture in long foraging trips to replenish their own energy reserves (Weimerskirch et al. 1994a, 1997). The body mass of breeding black-footed and Laysan albatrosses declines during the incubation and the brooding periods, with the lowest body masses recorded prior to the onset of the long foraging trips. Thereafter, adult albatrosses gain weight through the rearing period (Whittow 1993b). Conversely, chicks gain weight through midMay, when they are heavier than their parents. Subsequently, their body mass declines as feeds become smaller and less frequent (Rice \& Kenyon 1962, Fisher 1967). Additional studies are necessary to assess how energetic demands constrain albatross foraging strategies. In particular, it is essential to understand how adult and chick body condition influence the range and duration of foraging trips throughout the breeding season, and how albatross foraging behavior responds to interannual variability in ocean productivity and prey availability (e.g. Veit \& Prince 1997, Weimerskirch \& Cherel 1998, Duriez et al. 2000, Kitaysky et al. 2000).

\section{Small-scale habitats: the role of predictable physical features}

The large-scale (1000 to $3000 \mathrm{~km})$ dispersion of North Pacific marine turtles, predatory fishes, and seabirds is influenced by water mass distributions and 
frontal features (Wahl et al. 1989, Pearcy 1991, McKinnell \& Waddell 1993, Yatsu et al. 1993). Additionally, far-ranging predators frequently aggregate at smallerscale $(10$ to $100 \mathrm{~km}$ ) hydrographic and topographic features such as fronts, banks, and shelf breaks (Ogi 1984, Springer et al. 1996, Polovina et al. 2000, 2001). In particular, regions of enhanced productivity and prey aggregation, mediated by predictable physical processes, constitute important foraging grounds for surface-foraging marine birds (Schneider 1991, Hunt et al. 1999).

We previously documented that black-footed and Laysan albatrosses commuted to continental shelves during the rearing stage of the breeding season (Fernández et al. 2001). This study also revealed that rearing albatrosses also focused their foraging activities within highly productive continental shelves and in the vicinity of oceanic fronts. In particular, detailed behavioral analyses revealed that rearing albatrosses rapidly commuted to highly productive regions, where they engaged in area restricted searching behavior (Figs. 7, 9 \& 10). These results highlight the significance of highly productive foraging grounds for breeding North Pacific albatrosses, as well as the potential use of satellite tracked seabirds to monitor the productivity of vast pelagic environments.

\section{Continental shelves}

Rearing black-footed and Laysan albatrosses commuted to continental shelves along the West Coast of North America and the Aleutian Chain (Figs. 4, 5 \& 6; Fernández et al. 2001). It is well known that shelf breaks support elevated primary production and high standing stocks of zooplankton, fish and squid (Fournier et al. 1979, Springer et al. 1996). Two mechanisms have been invoked to explain prey aggregations at shelf breaks. First, high primary production rates stimulate the localized growth of higher trophic levels; and second, shelf break fronts aggregate prey produced elsewhere (Schneider 1991, Springer et al. 1996).

Previously, marine ornithologists have documented the tendency of albatrosses to aggregate along bathymetric discontinuities, likely in response to enhanced prey availability. For instance, wandering albatross Diomedea exulans and black-browed albatrosses D. melanophris are known to forage along shelf breaks and shallow banks in the vicinity of their breeding colonies (Weimerskirch et al. 1994a, Cherel \& Weimerskirch 1995, Gremillet et al. 2000).

\section{The North Pacific Transition Zone}

The satellite tracked black-footed and Laysan albatrosses foraged along the North Pacific Transition
Zone, a vast region extending from 28 to $45^{\circ} \mathrm{N}$ in the central Pacific Ocean $\left(160^{\circ} \mathrm{E}\right.$ to $\left.130^{\circ} \mathrm{W}\right)$. This broad transition zone separates the Subarctic Domain to the north from the Subtropical Gyre to the south, and is characterized by a series of convergence fronts where cold subartic water sinks under warmer subtropical water (Favorite et al. 1976, Roden 1991). These fronts support the highest standing stocks of micronekton (small squids, small fishes and crustaceans) in the North Pacific during the boreal spring and summer (Aron 1962, Pearcy 1991), and represent important feeding grounds for far ranging fishes, seabirds, and turtles (Ogi 1984, McKinnell \& Waddell 1993, Polovina et al. 2000, 2001).

In particular, subtropical species such as the albacore tuna Thunnus alalunga and the loggerhead turtle Caretta caretta forage along the North Pacific Transition Zone Chlorophyll Front (TZCF), a dynamic frontal system characterized by surface convergence (Polovina et al. 2000, 2001). This dynamic frontal feature spanned the foraging ranges of the satellite tracked black-footed and Laysan albatrosses, and migrated by approximately $10^{\circ}$ latitude between January and March (28 to $35^{\circ} \mathrm{N}$ ), and between July and September ( 38 to $45^{\circ} \mathrm{N}$ ) of 1998 (Polovina et al. 2001).

Persistent oceanic fronts have long been recognized as regions of elevated biological activity in pelagic systems (Aron 1962, Pearcy 1991, Gong et al. 1993, Olson et al. 1994). Albatross aggregations along frontal regions in the Southern Ocean have been documented previously. For instance, over $95 \%$ of the blackbrowed albatross sighted along the Weddell-Scotia confluence were concentrated in a $10 \mathrm{~km}$ section (Veit \& Hunt 1992). Additionally, satellite tracked blackbrowed albatross breeding at South Georgia repeatedly commuted to the Antarctic Polar Front to forage on squid (Rodhouse et al. 1996).

\section{Fishing effort distributions}

Black-footed and Laysan albatrosses are known to consume fisheries discards and to aggregate at vessels throughout their marine range (Wahl \& Heinemann 1979, Gould et al. 1997, Boggs 2001, Hyrenbach 2001, Stehn et al. 2001). Both fishing fleets and albatrosses exploit the same highly productive oceanic areas, and the birds likely feed on fisheries discards coincidentally (Gong et al. 1993, Yatsu et al. 1993, Cherel et al. 2000, Gremillet et al. 2000). Thus, it is likely that small-scale (1 to $10 \mathrm{~km}$ ) albatross distributions within highly productive coarse-meso scale (10 to $100 \mathrm{~km}$ ) foraging grounds are influenced by the presence of trawling and longline fishing vessels. 


\section{Pelagic segregation of black-footed and Laysan albatrosses}

Our satellite telemetry study has revealed that 2 sympatrically breeding Hawaiian albatrosses use different large-scale and small-scale oceanic habitats. Over macro-mega scales (1000 to $3000 \mathrm{~km}$ ) this pelagic segregation is underscored by disjunct foraging ranges (e.g. low activity range overlap) (Figs. 5 \& 6) and disparate habitat use patterns (e.g. sea surface temperature, chlorophyll concentration) (Figs. 2 \& 3). During the brooding period of the breeding season, blackfooted albatross foraged south of the Subtropical Front, and along the southern edge of the North Pacific Transition Zone Chlorophyll Front. Conversely, Laysan albatross ranged farther northward into cooler and more productive Transition Domain and Subarctic waters. This interspecific segregation became more apparent during the rearing stage, in conjunction with marked gender-based differences within species. The foraging ranges of both genders and species expanded during the rearing stage, and the overlap between the activity ranges declined (Table 7). Rearing blackfooted albatross alternated foraging trips to tropical and subtropical waters south of the Subtropical Frontal Zone with commuting flights to the West Coast of North America. Conversely, Laysan albatross foraged predominantly north of the Transition Domain, within subarctic waters of the Gulf of Alaska, the northwestern Pacific, the Bering Sea, and the Aleutian Islands (Figs. 5, 6 \& 11; Fernández et al. 2001).

Moreover, the disparities in black-footed and Laysan albatrosses time at sea distributions (Fig. 11) and core foraging areas (25\% time at sea isopleths; Figs. $5 \& 6)$ also suggest that these sympatrically breeding species exploited different coarse-meso scale (10 to $100 \mathrm{~km}$ ) habitats mediated by distinct physical processes. In particular, we hypothesize that black-footed albatross foraged along convergent fronts in search of flying fish (Exocoetid) eggs, floating carrion, and other buoyant prey items, while Laysan albatross foraged for squid and fish within highly productive Transition Domain and subarctic waters (Harrison et al. 1983, Gould et al. 1997).

Black-footed albatross concentrated their foraging activities offshore of predictable coastal upwelling regions (West Coast of North America) and along oceanic frontal systems (Subtropical Front). Convergence zones downstream from upwelling centers off central California support dense aggregations of surface foraging seabirds such as phalaropes (Phalaropus spp.), and their planktonic and larval fish prey (Briggs et al. 1984, Larson et al. 1994). Convergence of surface waters also aggregates buoyant prey and debris along oceanic fronts. For instance, surveys of plastic and tar

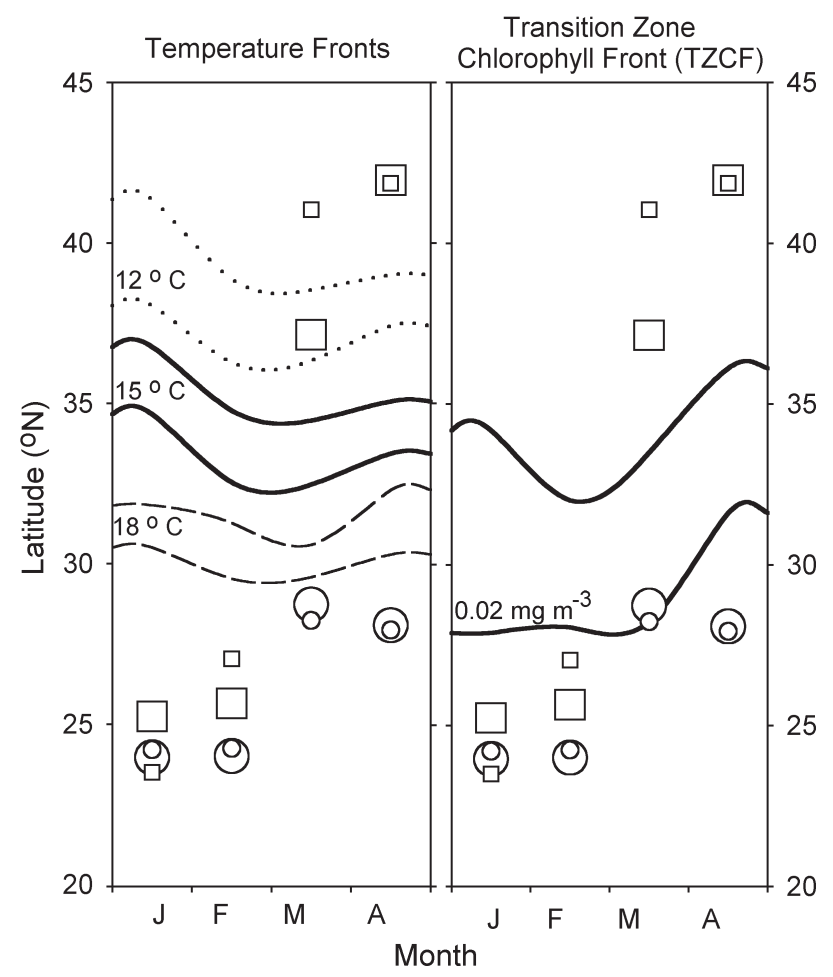

Fig. 11. Association of satellite tracked albatrosses and frontal features in the North Pacific Transition Domain $\left(20\right.$ to $45^{\circ} \mathrm{N}$, $160^{\circ} \mathrm{E}$ to $\left.130^{\circ} \mathrm{W}\right)$. Mean latitude of brooding (January to February) and rearing (March to April) black-footed (circles) and Laysan (squares) albatrosses were derived from monthly time at sea estimates. The monthly average (mean $\pm \mathrm{SD}$ ) latitude of the Subtropical $\left(18^{\circ} \mathrm{C}\right.$, dashed lines $)$, Transition Zone $\left(15^{\circ} \mathrm{C}\right.$, solid lines) and Subarctic $\left(12^{\circ} \mathrm{C}\right.$, dotted lines) fronts, and the North Pacific Transition Zone Chlorophyll Front $(0.2 \mu \mathrm{g}$ chl a $\mathrm{m}^{-3}$ ) were derived from sea surface temperature (AVHRR) and chlorophyll (SeaWiFS) imagery. The larger and smaller symbols depict males and females respectively.

distributions in the North Pacific Ocean have revealed concentrations of floating debris within subtropical waters in the vicinity of the frontal systems (32 to $40^{\circ} \mathrm{N}$ ) separating subtropical and subarctic waters (Shaw \& Mapes 1979, Dahlberg \& Day 1985). These aggregations have been ascribed to the convergence of surface waters at 30 to $35^{\circ} \mathrm{N}$ and 40 to $42^{\circ} \mathrm{N}$ due to the prevailing wind patterns in the North Pacific (Galt 1985, Kubota 1994). There is mounting evidence that far-ranging pelagic species forage on prey aggregated along these convergence zones. In particular, loggerhead turtles and albacore tuna are known to forage on gelatinous zooplankton, crustaceans and squid along the North Pacific Transition Zone Chlorophyll Front, a region of strong surface convergence associated with chlorophyll concentrations of ca. $0.2 \mathrm{mg} \mathrm{m}^{-3}$, and sea surface temperatures between 17 and $20^{\circ} \mathrm{C}$ (Polovina et al. 2000, 2001). 
On the other hand, Laysan albatross probably foraged for squid, Pacific saury Cololabis saira, myctophids (Myctophidae) and pomfret Brama japonica within Transition Domain and Subarctic waters (Harrison et al. 1983, Ogi 1984, Gould et al. 1997). The Transition Domain supports the highest standing stocks of squid and mesopelagic fish in the North Pacific during the boreal spring and summer (Aron 1962). In particular, North Pacific neon flying squid Ommastrephes bartrami catches in the Japanese high-seas fishery (1983-1990) are highest in regions of sea surface temperature between 15 and $16^{\circ} \mathrm{C}$ (Gong et al. 1993, Yatsu et al. 1993). Moreover, vessel-based surveys suggest that this frontal system represents an important foraging area for far-ranging seabirds such as shearwaters and albatrosses. For instance, Ogi (1984) described large numbers of sooty shearwaters Puffinus griseus feeding on dense saury aggregations along the Subarctic Boundary (SST: 9 to $13^{\circ} \mathrm{C}$ ) during summer and fall (July to October). Similarly, Gould (1983) reported Laysan albatross aggregations along the northern edge of the Transition Domain during fall (October to November).

Additionally, Laysan albatross commuted to shallow waters along the Aleutian Islands to exploit regions of high (150 to $200 \mathrm{gC} \mathrm{m}^{-2} \mathrm{yr}^{-1}$ ) ocean productivity supported by tidal mixing along narrow passes such as Unimak Pass $\left(53^{\circ} 10^{\prime} \mathrm{N}, 169^{\circ} 08^{\prime} \mathrm{W}\right)$, and predictable tidal fronts associated with the $50 \mathrm{~m}$ isobath (Schneider et al. 1986, Springer et al. 1996, Hunt et al. 1999).

The spatial segregation we have documented in this study is consistent with previous studies of dietary preferences and marine distributions of North Pacific albatrosses. Black-footed and Laysan albatrosses have broad diets including carrion, pyrosomes, Velella velella ('by-the-wind-sailor'), pelagic barnacles (Lepas spp.), fish and squid (Whittow et al. 1993a,b). However, black-footed albatross rely more heavily on carrion and offal, and their diet consists largely of flying fish eggs ( $50 \%$ by volume), squid ( $32 \%$ by volume) and crustaceans ( $5 \%$ by volume). Laysan albatross, on the other hand, feed mostly on squid (65\% by volume, largely neon flying squid), fish (9\% by volume) and crustaceans (9\% by volume) (Harrison et al. 1983, Gould et al. 1997).

The ecological significance of these disparate dietary preferences is reinforced by evidence of distinct blackfooted and Laysan albatross marine distributions outside of the breeding season. For instance, the analysis of catches by the Japanese high-seas driftnet fishery during summer and fall (June to September, 1988 to 1990) revealed 2 persistent species assemblages across the central North Pacific $\left(170^{\circ} \mathrm{E}\right.$ to $\left.145^{\circ} \mathrm{W}\right)$ (McKinnell $\&$ Waddell 1993). The black-footed albatross was clas- sified as a warm-water, eastern species, along with various tunas and marine turtles. On the other hand, the Laysan albatross was a member of a cold-water, western assemblage, along with various salmon species (Onchorhynchus spp.) and subarctic seabirds such as the sooty shearwater. These distinct faunal associations suggest that black-footed and Laysan albatrosses inhabit physically and biologically distinct oceanic habitats.

Previous at sea observations and bycatch studies revealed that black-footed and Laysan albatross marine distributions are spatially segregated (Shuntov 1974, Wahl et al. 1989, Whittow 1993a,b). These conclusions, however, were largely based on the distributions of birds of unknown reproductive status and origin. Earlier, we used satellite tracking to document the pelagic segregation of these 2 sympatric species (Fernández et al. 2001). The analysis of satellite tracking, in conjunction with remotely sensed environmental information, provides conclusive evidence of distinct habitat use patterns of sympatrically breeding blackfooted and Laysan albatrosses during the brooding and rearing periods of the breeding season.

\section{CONCLUSIONS}

Our study suggests that marine bird distributions are influenced by scale-dependent processes and constrained by energetic considerations. The analysis of telemetry tracks with respect to oceanic habitats revealed that albatross distributions are scale-dependent, and that distinct processes influence marine bird dispersion at different scales (Hunt \& Schneider 1987, Schneider 1991). Namely, over large spatial scales (1000 to $3000 \mathrm{~km}$ ) albatross foraging ranges were influenced by water mass distributions and constrained by breeding duties at the colony. Conversely, predictable physical processes that aggregate prey (convergence: black-footed albatross) and promote ocean productivity (mixing: Laysan albatross) probably influenced albatross distributions over smaller coarsemeso scales (10 to $100 \mathrm{~km}$ ).

This research also emphasizes the need to interpret seabird distributions and habitat use patterns in the context of life history limitations. Seabird foraging strategies are likely constrained by the dispersion and availability of different prey resources, by the energetic costs of foraging, and by the rate at which energy must be delivered to the nest. Therefore, additional research is needed to determine how prey dispersion, flight costs, and energetic demands influence the foraging patterns of North Pacific albatrosses. For instance, future studies could address whether blackfooted and Laysan albatrosses allocate resources dif- 
ferently during long and short foraging trips. This would require understanding how the energetic demands, the body condition, the foraging destinations, and the diet of foraging albatrosses change during different foraging trips, periods of the breeding season, and years of contrasting prey abundance (Weimerskirch et al. 1997, Weimerskirch \& Cherel 1998, Duriez et al. 2000, Kitaysky et al. 2000).

Multidisciplinary research programs including oceanography, satellite telemetry, dietary analyses, energetics, and demography are necessary to grasp the ecological and evolutionary forces shaping seabird dispersion, habitat selection, and foraging behavior. Such studies must also incorporate an understanding of the tradeoffs between current reproduction and adult survivorship, which are known to influence seabird foraging and reproductive strategies (Lack 1968, Weimerskirch et al. 1997, Weimerskirch \& Cherel 1998, Duriez et al. 2000).

Acknowledgements. We are grateful to all those who facilitated the collection and analysis of the data used in this study. We thank L. Carsten, F. Juola, P. Sievert, A. Viggiano, S. Wang for their assistance in the field, and E. Flint and the US Fish and Wildlife Service for logistical support at Tern Island. The Pacific Fisheries Environmental Lab (PFEL) and NASA provided the AVHRR and SeaWiFS satellite imagery used in this study. A. De Robertis and J. Pringle furnished valuable Matlab suggestions, and J.-D. Lebreton provided statistical advice. P. Dayton, P. Franks, G. Hunt, J. Jaffe, K. Roy, P. Sagar, and 3 anonymous referees provided helpful comments on an earlier draft of this manuscript. This research was funded by a National Science Foundation grant DEB 9629539 to D.J.A., and completed in partial fulfillment of K.D.H.'s PhD requirements at the Scripps Institution of Oceanography.

\section{LITERATURE CITED}

Aebischer NJ, Robertson PA, Kenward RE (1993) Compositional analysis of habitat use from animal radio-tracking data. Ecology 74:1313-1325

Anderson DJ, Schwandt AJ, Douglas HD (1998) Foraging ranges of waved albatrosses in the Eastern Tropical Pacific Ocean. In: Robertson G, Gales R (eds) Albatross biology and conservation. Surrey Beatty and Sons, Chipping Norton, p 180-185

Argos (1989) Guide to the Argos System. Argos CLS, Toulouse

Aron W (1962) The distribution of animals in the eastern North Pacific and its relationship to physical and chemical conditions. J Fish Res Board Can 19:271-314

Barber RT, Smith RL (1981) Coastal upwelling ecosystems. In: Longhurst AR (ed) Analysis of marine ecosystems. Academic Press, New York, p 31-68

Boggs C (2001) Deterring albatrosses from contacting baits during swordfish longline sets. In: Melvin E, Parrish J (eds) Seabird bycatch: trends, roadblocks, and solutions. Alaska Sea Grant, Fairbanks, p 79-94

Briggs KT, Dettman KF, Lewis DB, Tyler WB (1984) Phalarope feeding in relation to autumn upwelling of California.
In: Nettleship DN, Sanger GA, Springer PF (eds) Marine birds: their feeding ecology and commercial fisheries relationships. Canadian Wildlife Service Special Publication. Canadian Wildlife Service, Ottawa, p 51-62

Cherel Y, Weimerskirch H (1995) Seabirds as indicators of marine resources: black-browed albatrosses feeding of ommastrephid squids in Kerguelen waters. Mar Ecol Prog Ser 129:295-300

Cherel Y, Weimerskirch H, Trouve C (2000) Food and feeding ecology of the neritic-slope forager black-browed albatross and its relationships with commercial fisheries in Kerguelen waters. Mar Ecol Prog Ser 207:183-199

Dahlberg ML, Day RH (1985) Observations of man-made objects on the surface of the North Pacific. In: Shomura, RS, Yoshida HO (eds) Proceedings of the workshop on the fate and impact of marine debris, 27-29 November 1984 Honolulu, Hawaii. US Department of Commerce, Honolulu, p 198-212

Duriez O, Weimerskirch H, Fritz H (2000) Regulation of chick provisioning in the thin-billed prion: an interannual comparison and manipulation of parents. Can J Zool 78: 1275-1283

Favorite F, Dodimead AJ, Nasu K (1976) Oceanography of the Subarctic Pacific region. Int North Pac Fish Comn Bull 33:1-187

Fernández P, Anderson DJ (2000) Nocturnal and diurnal foraging activity of Hawaiian albatrosses detected with a new immersion monitor. Condor 102:577-584

Fernández P, Anderson DJ, Sievert PR, Huyvaert JP (2001) Foraging destinations of three low-latitude albatross species. J Zool 254:391-404

Fitzpatrick GL, Modlin MJ (1986) Direct line distances (United States Edition). Scarecrow Press, Metuchen

Fisher HI (1967) Body weights of Laysan albatrosses Diomedea immutabilis. Ibis 109:373-382

Fournier RO, Van Det M, Wilson JS, Hargreaves NB (1979) Influence of the shelf-break off Nova Scotia on phytoplankton standing stock in winter. J Fish Board Can 36: 1228-1237

Franks PJS (1992) Swim or sink: accumulation of biomass at fronts. Mar Ecol Prog Ser 82:1-12

Galt JA (1985) Oceanographic factors affecting the predictability of drifting objects at sea. In: Shomura RS, Yoshida HO (eds) Proceedings of the workshop on the fate and impact of marine debris, 27-29 November 1984, Honolulu, Hawaii. US Department of Commerce, Honolulu, p 497-507

Gong Y, Kim S, An DH (1993) Abundance of neon flying squid in relation to oceanographic conditions in the North Pacific. Int North Pac Fish Comn Bull 53:191-204

Gonzalez-Solis J, Croxall JP, Wood AG (2000) Foraging partitioning between giant petrels Macronectes spp. and its relationship with breeding population changes at Bird Island, South Georgia. Mar Ecol Prog Ser 204:279-288

Gould PJ (1983) Seabirds between Alaska and Hawaii. Condor 85:286-291

Gould PJ, Ostrom P, Walker W (1997) Trophic relationships of albatrosses associated with squid and large-mesh driftnet fisheries in the North Pacific Ocean. Can J Zool 75: 549-562

Gremillet D, Wilson RP, Wanless S, Chater T (2000) Blackbrowed albatrosses, international fisheries and the Patagonian shelf. Mar Ecol Prog Ser 195:269-280

Harrison CS, Hida TS, Seki MP (1983) Hawaiian seabird feeding ecology. Wildl Monogr 85:1-71

Haury LR, McGowan JA, Wiebe PH (1978) Patterns and processes in the time-space scales of plankton distributions. 
In: Steele JH (ed) Spatial patterns in plankton communities. Plenum Press, New York, p 277-327

Hooge PN, Eichenlaub B (1997) Animal movement extension to Arcview, version 1.1. US Geological Survey, Anchorage

Hunt GL Jr, Schneider DC (1987) Scale dependent processes in the physical and biological environment of seabirds. In: Croxall JP (ed) The feeding ecology of seabirds and their role in marine ecosystems. Cambridge University Press, Cambridge, p 7-41

Hunt GL Jr, Mehlum F, Russell RW, Irons D, Decker MB, Becker PH (1999) Physical processes, prey abundance, and the foraging ecology of seabirds. In: Adams NJ, Slotow RH (eds) Proc 22nd Int Ornithol Congr, Durban. Bird Life South Africa, Johannesburg, p 2040-2056

Hurlbert SH (1984) Pseudoreplication and the design of ecological field experiments. Ecology 54:187-211

Hyrenbach KD (2001) Albatross response to survey vessels: implications for studies of the distribution, abundance, and prey consumption of seabird populations. Mar Ecol Prog Ser 212:283-295

Jouventin P, Weimerskirch H (1990) Satellite tracking of wandering albatrosses. Nature 343:746-748

Kahru M, Mitchell BG (1999) Empirical chlorophyll algorithm and preliminary SeaWiFS validation for the California Current. Int J Remote Sens 20:3423-3429

Kitaysky AS, Hunt GL Jr, Flint EN, Rubega MA, Decker MB (2000) Resource allocation in breeding seabirds: responses to fluctuations in their food supply. Mar Ecol Prog Ser 206:283-296

Klimley AP (1993) Highly directional swimming by scalloped hammerhead sharks, Shyrna lewini, and subsurface irradiance, temperature, bathymetry, and geomagnetic field. Mar Biol 117:1-22

Kubota M (1994) A mechanism for the accumulation of floating marine debris north of Hawaii. J Phys Oceanogr 24:1059-1064

Lack D (1968) Ecological adaptations for breeding in birds. Methuen, London

Larson RJ, Lenarz WH, Ralstron S (1994) Distribution of juvenile rockfish of the genus Sebastes in the upwelling region of central California. CalCOFI (Calif Coop Oceanic Fish Invest) Rep 35:175-221

Longhurst A (1998) Ecological geography of the sea. Academic Press, San Diego

Lynn RJ (1986) The subarctic and northern subtropical fronts in the eastern North Pacific Ocean in spring. J Phys Oceanogr 16:209-222

McClain CR, Cleave ML, Feldman GC, Gregg WW, Hooker SB (1998) Science quality of the SeaWiFS data for global biosphere research. Sea Tech 39:10-17

McClain EP, Pichel WG, Walton CC (1985) Comparative performance of AVHRR-based multichannel sea surface temperatures. J Geophys Res 90:11587-11601

McKinnell S, Waddell B (1993) Associations of species caught in the Japanese large scale pelagic squid drifnet fishery in the Central North Pacific Ocean: 1988-1990. Int North Pac Fish Comn Bull 53:91-146

Nevitt G, Veit RR (1999) Mechanisms of prey-patch detection by foraging seabirds. In: Adams NJ, Slotow RH (eds) Proceedings 22nd International Ornithological Congress, Durban. Bird Life South Africa, Johannesburg, p 2072-2082

Nicholls DG, Murray MD, Butcher E, Moors P (1997) Weather systems determine the non-breeding distribution of wandering albatrosses over southern oceans. Emu 97:240-244

Ogi H (1984) Feeding ecology of the sooty shearwater in the western subarctic North Pacific Ocean. In: Nettleship DN, Sanger GA, Springer PF (eds) Marine birds: their feeding ecology and commercial fisheries relationships. Canadian Wildlife Service, Ottawa, p 78-84

Olson DB, Hitchcock GL, Mariano AJ, Ashjan CJ, Peng G, Nero RW, Podesta GP (1994) Life on the edge: marine life and fronts. Oceanography 7:52-60

Pearcy WG (1991) Biology of the transition region. In: Wetherall JA (ed) Biology, oceanography, and fisheries of the North Pacific transition zone and subarctic frontal zone: papers from the North Pacific Transition Zone workshop, 9-11 May 1988, NOAA Technical Report, NMFS 105. US Department of Commerce, Honolulu, p 39-55

Pennycuick CJ (1987) Flight of seabirds. In: Croxall JP (ed) The feeding ecology of seabirds and their role in marine ecosystems. Cambridge Univ Press, Cambridge, p 43-62

Polovina JJ, Kobayashi DR, Parker DM, Seki MP, Balazs GH (2000) Turtles on the edge: movement of loggerhead turtles (Caretta caretta) along oceanic fronts spanning longline fishing grounds in the central North Pacific, 1997-1998. Fish Oceanogr 9:74-82

Polovina JJ, Howell E, Kobayashi DR, Seki MP (2001) The Transition Chlorophyll Front, a dynamic global feature defining migration and forage habitat for marine resources. Prog Oceanogr 49:469-483

Prince PA, Wood AG, Barton T, Croxall JP (1992) Satellite tracking of wandering albatrosses (Diomedea exulas) in the South Atlantic. Antarct Sci 4:31-36

Prince PA, Weimerskirch H, Wood AG, Croxall JP (1999) Areas and scales of interactions between albatrosses and the marine environment: species, populations and sexes. In: Adams NJ, Slotow RH (eds) Proc 22nd Int Ornithol Congr, Durban. Bird Life South Africa, Johannesburg, p 2001-2020

Reynolds RW, Smith TM (1994) Improved global sea surface temperature analyses using optimum interpolation. J Clim 7:929-948

Rice DW, Kenyon KW (1962) Breeding cycles and behaviour of Laysan and black-footed albatrosses. Auk 79:517-567

Roden GI (1991) Subarctic-subtropical transition zone of the North Pacific: Large scale aspects and mesoscale structure. In: Wetherall JA (ed) Biology, oceanography, and fisheries of the North Pacific transition zone and subarctic frontal zone: papers from the North Pacific Transition zone workshop, 9-11 May 1988. NOAA Tech Rep NMFS 105. US Department of Commerce, Honolulu, p 1-38

Rodhouse PG, Prince PA, Trathan PN, Hatfield EMC, Watkins JL, Bone DG, Murphy, EJ, White MJ (1996) Cephalopods and mesoscale oceanography at the Antarctic Polar Front: satellite tracked predators locate pelagic trophic interactions. Mar Ecol Prog Ser 136:37-50

Sagar PM, Weimerskirch H (1996) Satellite tracking of southern Buller's albatrosses from the Snares, New Zealand. Condor 98:649-652

Schneider DC (1991) The role of fluid dynamics in the ecology of marine birds. Oceanogr Mar Biol Annu Rev 29:487-521

Schneider DC, Hunt GL Jr, Harrison NM (1986) Mass and energy transfer to pelagic birds in the southeastern Bering Sea. Cont Shelf Res 5:241-257

Seaman DE, Powell RA (1996) An evaluation of the accuracy of kernel density estimators for home range analysis. Ecology 77:2075-2085

Shaw DG, Mapes GA (1979) Surface circulation and the distribution of pelagic tar and plastic. Mar Pollut Bull 10: 160-162

Shuntov VP (1974) Seabirds and the biological structure of the Ocean. Produced by the National Technical Information Service. US Department of Commerce, Springfield (English translation from Russian) 
Spear LB, Ainley DG (1997) Flight speed of seabirds in relation to wind speed and direction. Ibis 139:234-251

Springer AM, McRoy CP, Flint MV (1996) The Bering Sea Green Belt: shelf-edge processes and ecosystem production. Fish Oceanogr 5:205-223

Stahl JC, Sagar PM (2000a) Foraging strategies of southern Buller's albatrosses Diomedea $b$. bulleri breeding on The Snares, New Zealand. J R Soc NZ 30:299-318

Stahl JC, Sagar PM (2000b) Foraging strategies and migration of southern Buller's albatrosses Diomedea b. bulleri breeding on the Solander Is, New Zealand. J R Soc NZ 30:319-334

Stahl JC, Jouventin P, Mougin JL, Roux JP, Weimerskirch H (1985) The foraging zones of seabirds in the Crozet Islands sector of the Southern Ocean. In: Siegfried WR, Condy PR, Laws RM (eds) Antarctic nutrient cycles and food webs. Proceedings of the 4th Symposium on Antarctic Biology. Springer-Verlag, Berlin, p 478-486

Stehn RA, Rivera K, Fitzgerald S, Wohl K (2001) Incidental catch of seabirds by longline fisheries in Alaska. In: Melvin E, Parrish J (eds) Seabird bycatch: trends, roadblocks, and solutions. Alaska Sea Grant, Fairbanks, p 61-77

Veit RR (1999) Behavioural responses by foraging petrels to swarms of Antarctic krill Euphausia superba. Ardea $87: 41-50$

Veit RR, Hunt GL Jr (1992) The spatial dispersion of seabirds near the South Orkney Islands and the Weddell-Scotia confluence. Polar Biol 11:637-641

Veit RR, Prince PA (1997) Individual and population level dispersal of black-browed Diomedea melanophris and greyheaded albatrosses D. Chrysostoma in response to Antarctic krill. Ardea 85:129-134

Vinogradov ME (1981) Equatorial upwelling systems. In: Longhurst AR (ed) Analysis of marine ecosystems. Academic Press, New York, p 69-93

Vinogradov ME, Shushkina EA, Vedernikov VI, Nezlin NP, Gagarin VI (1997) Primary production and plankton stocks in the Pacific Ocean and their seasonal variation according to remote sensing and field observations. Deep-Sea Res Part II 44:1979-2001

Wahl TR, Heinemann D (1979) Seabirds and fishing vessels: co-occurrence and attraction. Condor 81:390-396

Wahl TR, Ainley DG, Banadict AH, DeGange AR (1989) Associations between seabirds and water-masses in the northern Pacific Ocean in summer. Mar Biol 103:1-11

Warham J (1977) Wing loadings, wing shapes, and flight capabilities of Procellariiformes. NZ J Zool 4:73-83

Warham J (1990) The petrels: their ecology and breeding systems. Academic Press, New York

Editorial responsibility: Otto Kinne (Editor),

Oldendorf/Luhe, Germany
Warham J, Watts R, Dainty RJ (1976) The composition, energy content and functions of stomach oil of petrels (order Procellariiformes). J Exp Biol Ecol 21:1-13

Waugh SM, Weimerskirch H, Cherel Y, Shankar U, Prince PA, Sagar PM (1999) Exploitation of the marine environment by two sympatric albatrosses in the Pacific Southern Ocean. Mar Ecol Prog Ser 177:243-254

Weimerskirch H, Cherel Y (1998) Feeding ecology of shorttailed shearwaters breeding in Tasmania and foraging in the Antarctic? Mar Ecol Prog Ser 167:261-274

Weimerskirch $\mathrm{H}$, Chastel $\mathrm{O}$, Ackermann L, Chaurand $\mathrm{T}$, Cuenot-Chaillet F, Hindermeyer X, Judas J (1994a) Alternate long and short foraging trips in pelagic seabird parents. Anim Behav 47:472-476

Weimerskirch H, Doncaster CP, Cuenot-Chaillet K (1994b) Pelagic seabirds and the marine environment: foraging patterns of wandering albatrosses in relation to prey availability and distribution. Proc R Soc Lond Ser B 255:91-97

Weimerskirch H, Cherel Y, Cuenot-Chaillet F, Ridoux V (1997) Alternative foraging strategies and resource allocation by male and female wandering albatrosses. Ecology 78:2051-2063

Weimerskirch H, Guionnet T, Martin J, Shaffer SA, Costa DP (2000) Fast and fuel efficient? Optimal use of wind by flying albatrosses. Proc R Soc Lond Ser B 267:1869-1874

Whittow GC (1993a) The black-footed albatross (Diomedea nigripes). In: Pooley A, Gill F (eds) The birds of North America, vol 65. The Academy of Natural Sciences, Philadelphia, p 1-16

Whittow GC (1993b) The Laysan albatross (Diomedea immutabilis). In: Pooley A, Gill F (eds) The birds of North America, vol 66. The Academy of Natural Sciences, Philadelphia, PA, p 1-20

Wilkinson L (1997) SYSTAT: the system for statistics. Systat Inc., Richmond, CA

Wolanski E, Hamner WH (1988) Topographically controlled fronts in the ocean and their biological importance. Science 241:177-181

Wood AG, Naef-Daenzer B, Prince PA, Croxall JP (2000) Quantifying habitat use in satellite-tracked pelagic seabirds: application of kernel estimation to albatross locations. J Avian Biol 31:278-286

Worton BJ (1989) Kernel methods for estimating the utilization distribution in home-range studies. Ecology 70:164-168

Yatsu A, Shimada H, Murata M (1993) Distributions of epipelagic fishes, squids, marine mammals, seabirds and sea turtles in the Central North Pacific. Int North Pac Fish Comn Bull 53:111-146

Zar JH (1984) Biostatistical analysis. Prentice-Hall, New York

Submitted: March 9, 2001; Accepted: September 4, 2001

Proofs received from author(s): April 15, 2002 